\title{
MULTIPLE GLACIATION AND GOLD-PLACER FORMATION, VALDEZ CREEK VALLEY, WESTERN CLEARWATER MOUNTAINS, ALASKA
}

By Richard D. Reger and Thomas K. Bundtzen

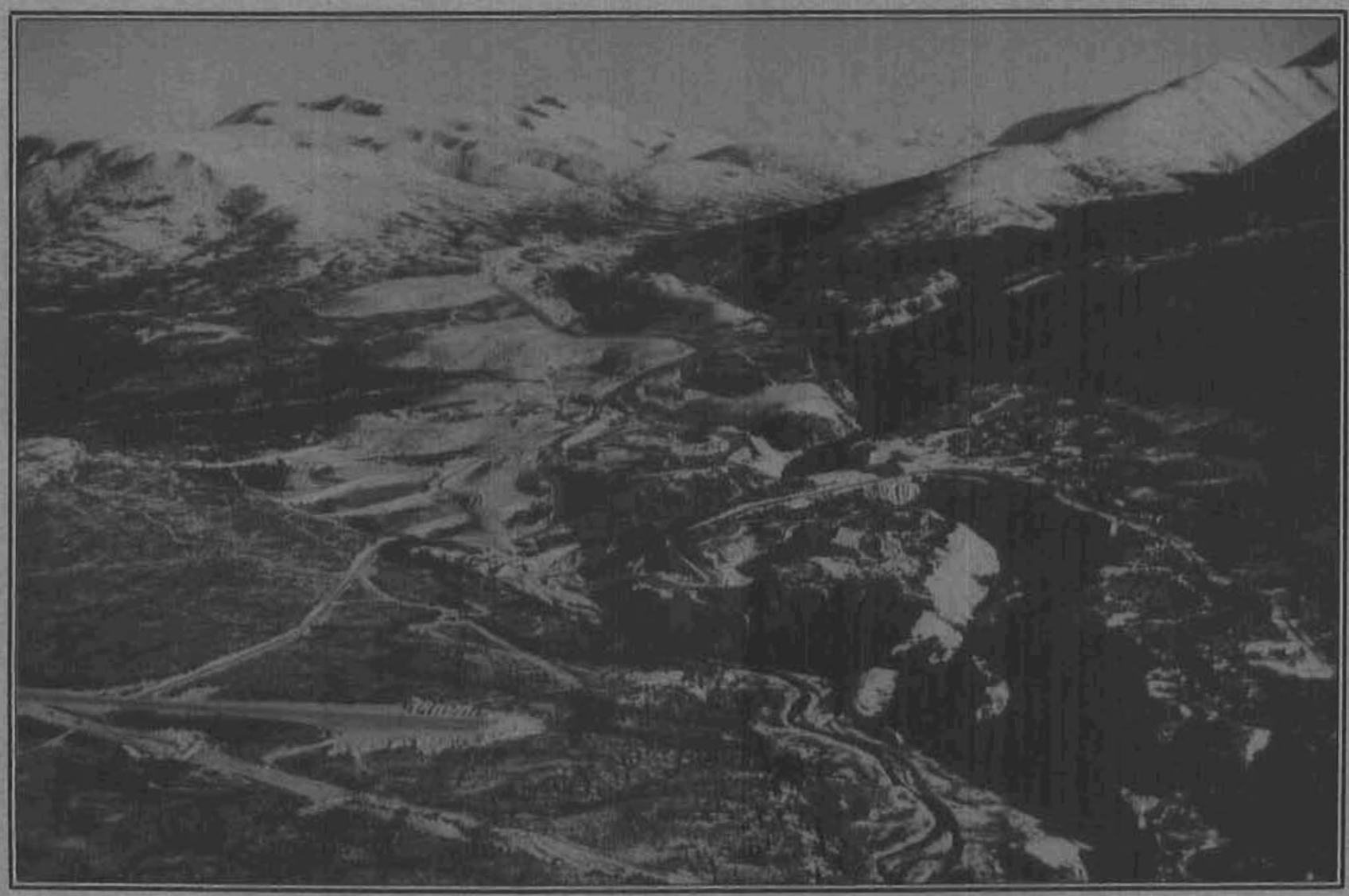

Professional Report 107

Publlshed by

STATE OF ALASKA

DEPARTMENT OF NATURAL RESOURCES

DIVISION OF GEOLOGICAL \& GEOPHYSICAL SURVEYS

1990

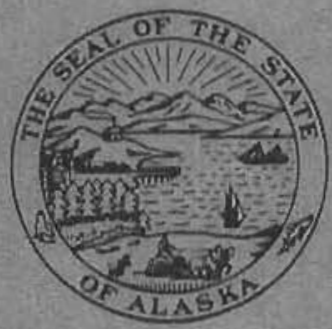




\section{MULTIPLE GLACIATION AND GOLD-PLACER \\ FORMATION, VALDEZ CREEK VALLEY, WESTERN CLEARWATER MOUNTAINS, ALASKA}

By Richard D. Reger and Thomas K. Bundtzen

Division of Geological \& Geophysical Surveys

Professional Report 107

Prepared in cooperation with U.S. Bureau of Mines

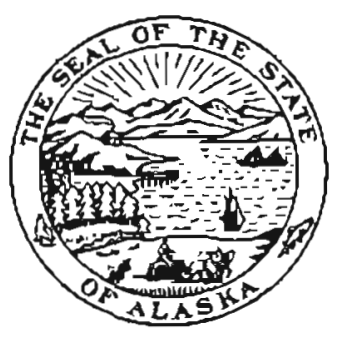

Fairbanks, Alaska 1990 


\author{
STATE OF ALASKA \\ Steve Cowper, Governor
}

DEPARTMENT OF NATURAL RESOURCES

Lennie Gorsuch, Commissioner

\title{
DIVISION OF GEOLOGICAL AND GEOPHYSICAL SURVEYS \\ Robert B. Forbes, Director and State Geologist
}

\footnotetext{
Cover: Oblique aerial view noriheast of Valdez Creek Mine and glacialed lower Valdez Creek valley. Photograph courtesy of Valdez Creek Mining Company.
} 


\section{CONTENTS}

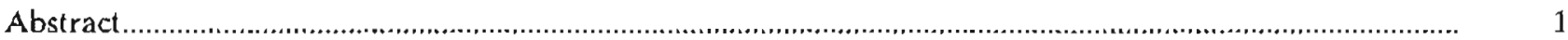

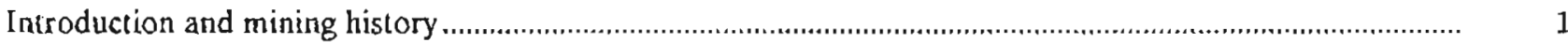

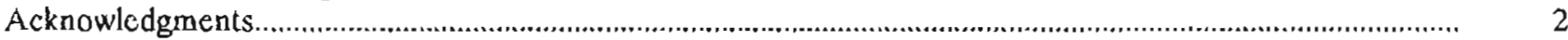

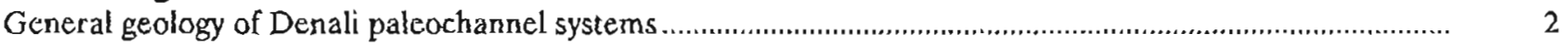

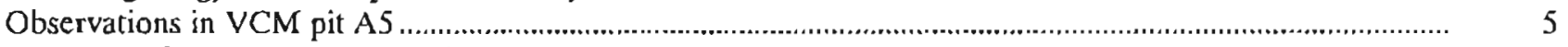

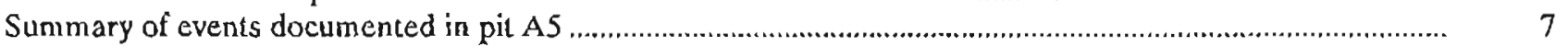

Formation of paleochannel $A$ and associated deposits ........................................................................... 7

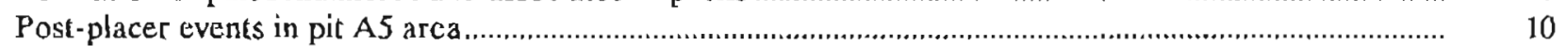

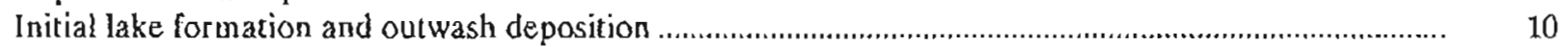

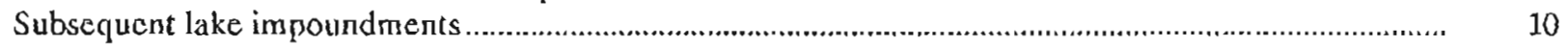

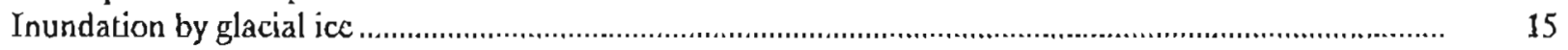

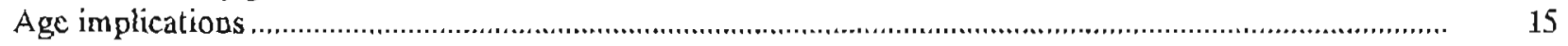

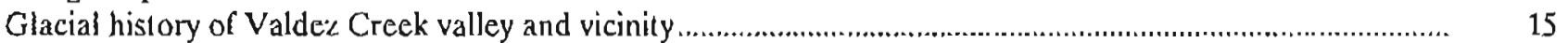

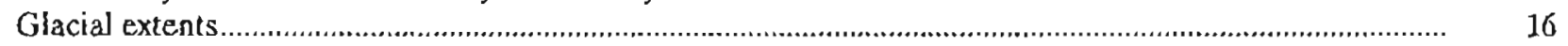

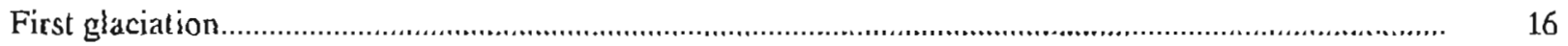

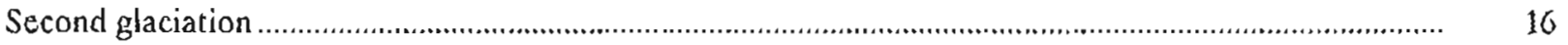

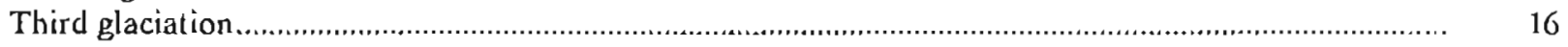

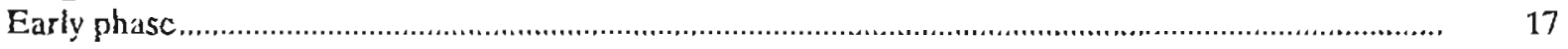

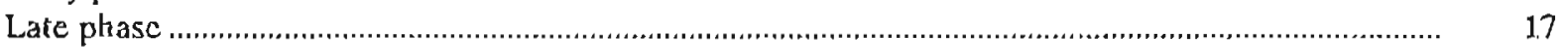

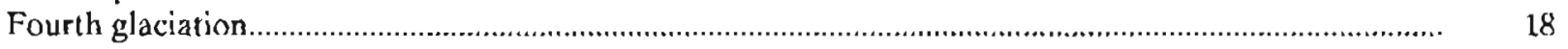

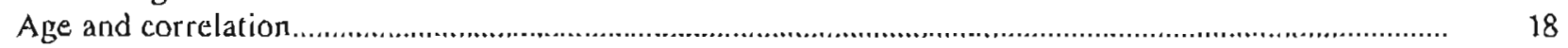

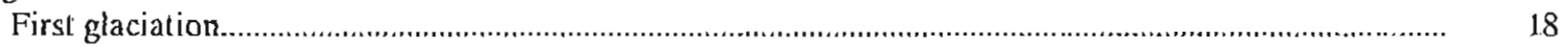

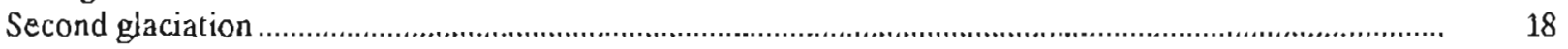

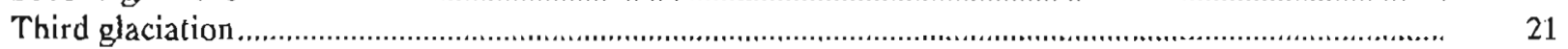

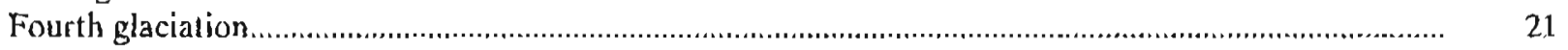

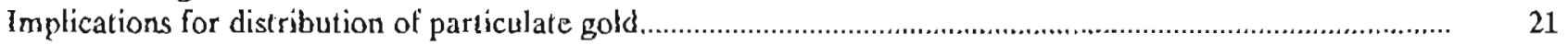

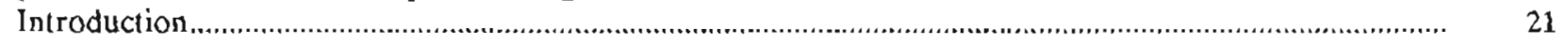

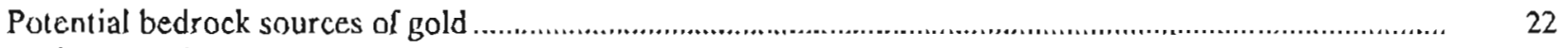

A placer-exploration model............................................................................................................. 22

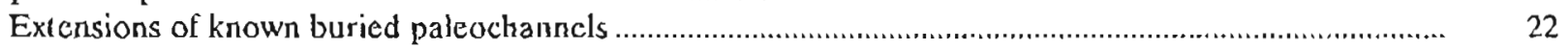

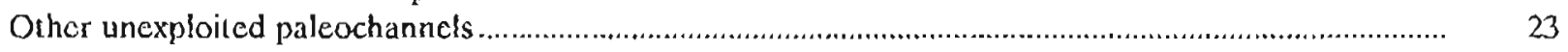

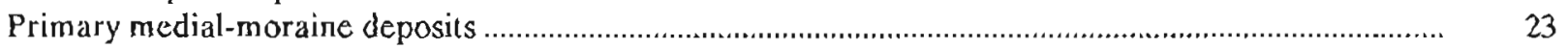

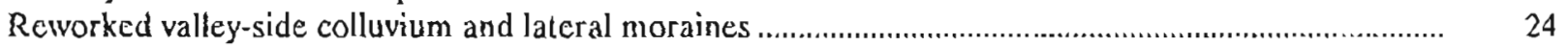

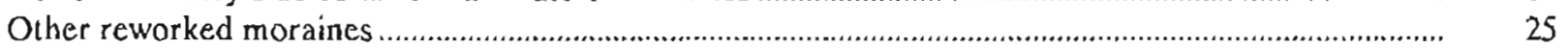

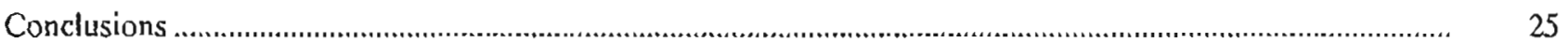

Relerences cited

\section{FIGURES}

Figure 1. Index map of central Alaska Range.................................................................................... 2

2. Diagram showing plan view of paleochannel systems in Valdcz Creek Mine .................................. 3

3. Diagram showing generalized stratigraphic section exposed August 5, 1988, in pit A5,
Valdez Creek Minc ....................................................................................................

4. Photograph of large granitic erratics in pay gravel at bottom of pit A5, Valdez Creek Mine............. 7

5. Photograph of thin-bedded (varved) silty fine sand in lower part of thick lacustrine section,

6. Photograph of medium-gray-brown organic fine sand at base of lower thick, lacustrine silty

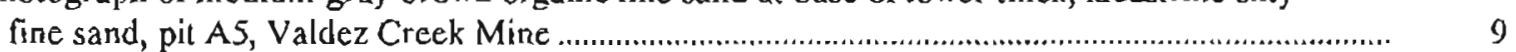

7. Chart comparing glacial chronologies in vicinity of Valdez Creek area ............................................. 


\section{TABLES}

Table 1. Summary of placer-gold and -silver production in Valdez Crcek mining district, 1904-89............... 4

2. Spore and pollen from silfy fine sand of lower part of varved lacustrine section, pit A3, Valdez Creek Mine ...............................................................................................................

3. Published radiocarbon dates of middle Wisconsin sediments from Alaska and Yukon Territory.... 12

4. Rad́iocarbon dates indicating timing of last recession of late Pleistocene ice in general area of

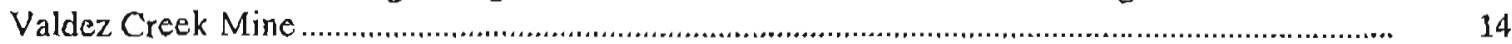

5. Exploration targets for placer-gold deposits in Valdez Creek valley ...............................................

\section{SHEET}

[In pocket]

Sheet 1. Photointerpretation of former glacial limits and associated landforms related to areas of significant gold-placer polential in Valdez Creek valley and vicinity, Alaska 


\title{
MULTIPLE GLACIATION AND GOLD-PLACER FORMATION, VALDEZ CREEK VALLEY, WESTERN CLEARWATER MOUNTAINS, ALASKA
}

\author{
By
Richard D. Reger' ${ }^{\text {and Thomas K. Bundtzen }}{ }^{1}$
}

\begin{abstract}
Stratigraphic observations and a photointerprelive study of the Valdez Creek area provide evidence for pre-Ilinoian, Mlinoian. Wisconsin, and Holocene glaciations in the westem Clearwater Mountains. Oniy a dissected remnant of the pre-Illinoian glacial trough is prescrved on the upper north wall of Valdez Creek valley. The inset lower valley of Valdez Creek was scoured during the Illinoian glaciation. At that time, most of the placer gold in the lower valley was probably liberated from lodes in the Gold Hill-Lucky Hill area and deposited initially in till. Early Wisconsin glaciation in the Valdez Creek drainago was less extensive than the late Wisconsin advance, whether ice was locally derived or came south from the central Alaska Range. During laze Wisconsin time, ice of the Susiura River glacier blocked Valdez Creek valley, producing an extensive ice-marginal lake that cventually filled with varved sediments, fan-della deposits, outwash gravel, and till.
\end{abstract}

Drilling by Valdez Creek Mining Company geologists indicates that at least three principal palcocharnel systems--A, $B$, and Tammany-and several subsidiary paleochannel systems were incised into bedrock in lower Valdez Creek valley. These paleochannels were filled by auriferous alluvial gravel and slightly retransported, auriferous till during former ice-free periods. Cumulative evidence indicalcs that palcochannel $A$ is Sangamon in ago and that Tammany paleochannel is mid-Wisconsin (Boutellicr) in age. Palcochannel $B$ was probably cut during a late Dlinoian inteystade. Recognition that early Wisconsin glacial advances were less extensive than talo Wisconsin advances in this part of the western Clearwater Mountions raises the possibility that buried pre-Wisconsin placers in other glaciatcd areas of Alaska are preserved within the limits of late Wisconsin glaciation.

Exploration targets for gold placers in the Valdez Creek area include (1) upchannel excensions of known buried paleachannels, (2) buried fans that compose downchannel extensions of known buried paleochannels, (3) other unexploited buried paleochannels, (4) medial-moraine deposits dowrvalley from the Gold Hill-Lucky Hill upland, (5) former

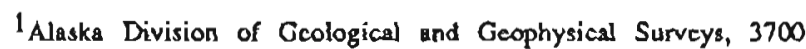
Airpont Way, Fairbanks, Alaska 99709.
}

courses of ice-marginal meltwater streams that reworked gold-bearing valley-side colluvium and till, and (6) zones where gold-bearing moraines were breached and reworked by late-glacial and postglacial axial and tributary streams.

\section{INTRODUCTION AND MINING HISTORY}

Valdez Creek mining district is locatcd in the westem Clearwater Mountaing of the southcentral Alaska Range (fig. 1). Placer gold was discovered on the alluvial fan downstream of the canyon of lower Valdez Creek (sheet 1) by a party of prospectors from Valdez on August 15, 1903 (Moffit, 1912; Tuck, 1938; Dessauer and Harvey, 1980). Further exploration upstream resulted in the discovery of rich bench gravels in the fall of 1904 in the lower north wall of the canyon. Subscquent exploitation of the north-bench gravels revealed that they were part of a dceply buried paleochannel cut into bedrock (fig. 2). This paleochannel, which became known as Tammany channel, was mined by operncut, hydraulic, and underground-drift methods; it contributed most of the gold recovered from Valdez. Creek mining district through the end of World War II (Smith, 1981).

For nearly $30 \mathrm{yr}$ following World War II, gold mining in Valdez Creek district was confined to small placer-mining ventures--including a hydraulic operation on Dry Creek (sheet 1)--and reconnaissance exploration drilling. Paleochannel A was discovered in 1981 by consulting geologist Don Stevens. WGM, Inc., operator for Camindex Mines, Inc., subsequently started a large-scale chum-drilling program on the upland bench in the vicinity of the former setulement of Denali (Bundtzen and others, 1984; sheet 1). In 1983 WGM announced discovery of several rich, superimposed paleochannels incised into bedrock of the upland beneath 30 to $100 \mathrm{~m}$ of glacial and glaciofluvial sediments. Large-scale mining began in 1984 and Valdez Creek Mining Company (VCMC), operator of the projecl, has produced $202,421 \mathrm{oz}(6,295 \mathrm{~kg})$ of refined 


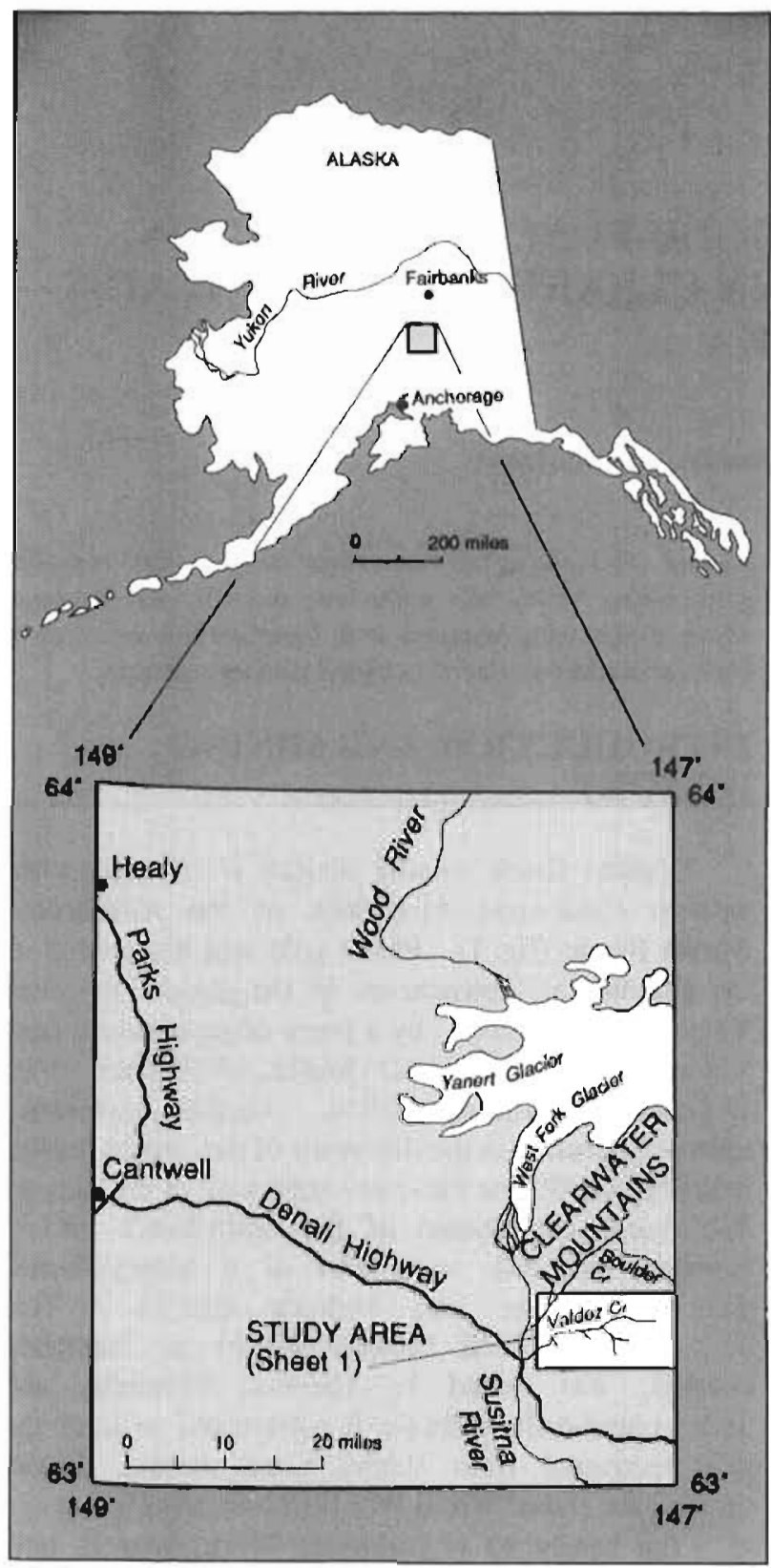

Figure 1. Index mup of cenural Alaska Range, showing location of study area.

gold, making Valdez. Creck Minc (VCM) Alaska's largest gold producer in 5 of the last 6 yr. Eventually, VCMC became fully owned by a joint-venture parinership that includes three Canadian firms: Camindex Mines Ltd. of Toronto, owning 51 percent; Cambior Inc. of Montreal, owning 25.9 percent; and American Barrick Resources, Lid, of Toronto, owning 23.1 percent. In 1988 the joint venture arranged a committce management system, in which Cambior Inc. provides the lead role (Hughes, 1989). In October 1989 the joint venture closed the mine until gold prices improve and issues concerning an expensive sueam-diversion project are resolved. Placer-gold reserves in VCMC's palcochannels now sland at 627,000 oz $(19,499 \mathrm{~kg})$, including $316,000 \mathrm{oz}(9,827 \mathrm{~kg})$ classified as proven or probable, which most likcly will insure fuere production from the properly. Total production from the Valdez Crcck districe from 1904 through 1989 is estimaled at $243,908 \mathrm{oz}(7,585 \mathrm{~kg})$ of gold and $36,201 \mathrm{o} \ell(1,122 \mathrm{~kg})$ of byproducl silver--virtually all of which was recovered from placers in the Valdez Creek drainage (table 1).

\section{ACKNOWLEDGMENTS}

Although Bunduen has studicd sediments in VCM since 1984, most of this stuody was accomplished during August 1988 while we were mapping cooperalively with the U.S. Bureau of Mines in the southcentral Alaska Range. Our work would not have been possible without the encouragement and cooperalion of the VCMC staff; we paricularly acknowledge the assistance of Richard Hughes (Mine Manager), Pete Oslund (former Mine Manager), Paul Marlin (Chicf Engineer), Jcrry O'Connor (Scnior Gcologist), Jim Wachter (Geologist), Rober 'Grog' Pelersen (Gcologisl), and Mary MacDonald (Goldroom Supervisor). Concepts presented in this repor benefited from discussions with several colleagucs: Mike Balen (U.S. Bureau of Mines), Jason Bressler (WGM, Inc.), Laurel Bums (DGGS), John Cook (U.S. Burcau of Land Management), Sleve Fechner (U.S. Bureau of Mines), Jerty Harris (University of Alaska Fairbanks), Davc Hopkins (University of Alaska Fairbanks), Tom Smith (DGGS), Stcve Teller (Universily of Alaska Fairbanks), and Milt Wiltse (DGGS). We appreciale reviews of this report by Jerry O'Connor, Tom Smith, and Mill Wiltse, and especially the thoughtful comments by Steve Teller, which considerably improved this paper. We gratefully acknowledge the editorial assistance of Karen Adams (DGGS).

\section{GENERAL GEOLOGY OF DENALI PALEOCHANNEL SYSTEMS}

In the vicinity of the forner town of Denali, mining-company geologists identificd at least threc principal, superimposed, gold-bearing paleochannels cut into bedrock subparallel to the modem canyon of lower Valdcz Creek and slightly offset to the northwest upstream of the sharp bend in the modem canyon (Bressler and olhers, 1985; Teller and Bressler, in press). Principal gold-bearing palcochannels have been designated (from youngest lo oldesl) Tammany paleochannel, discovered in 1904: A paleochannel, discovered by drilling 


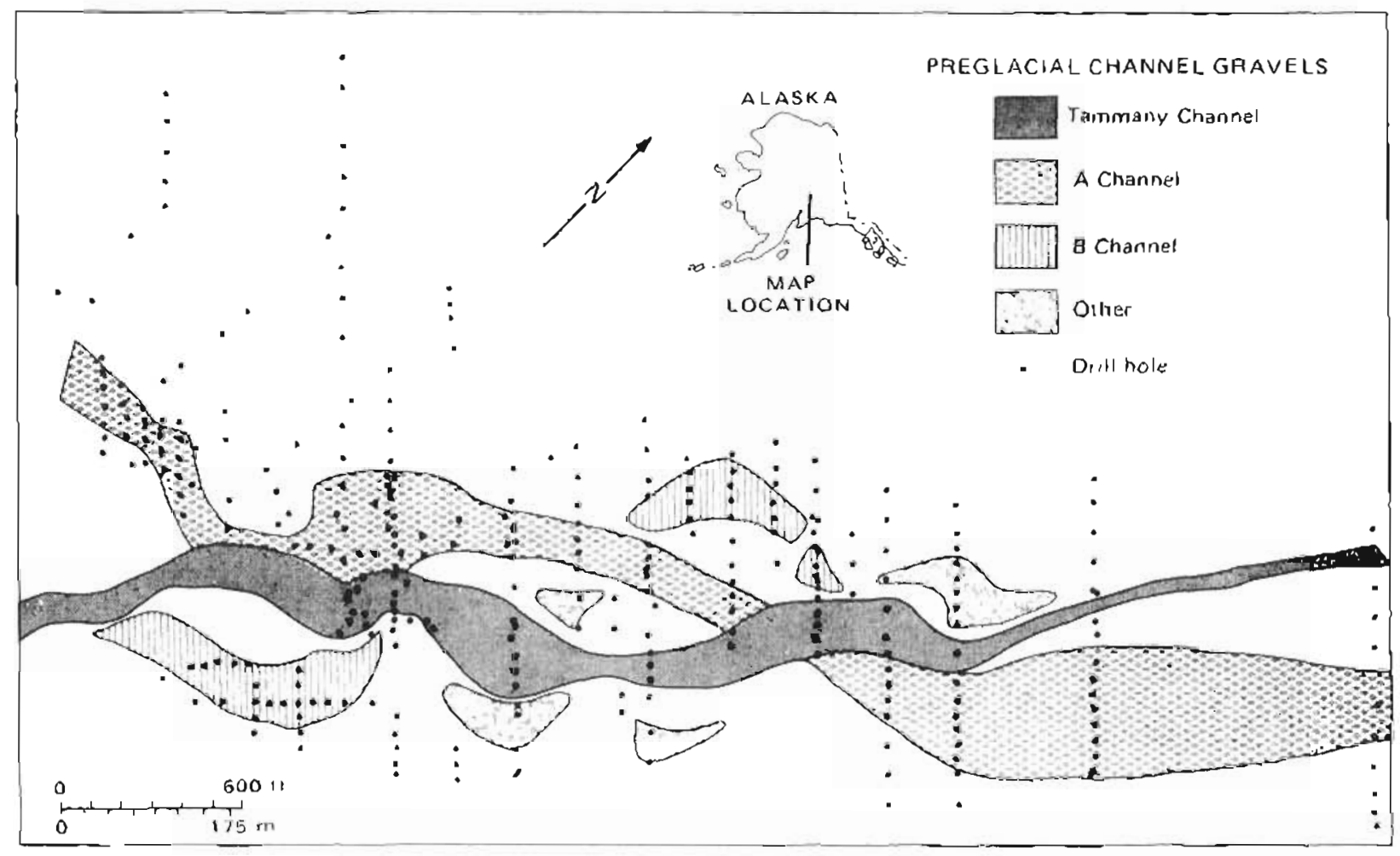

Figurc 2. Plan view of paleochannel systems in Valdez Creek Mine. From Eakins and orhers (1985, fig. 16) after Bresster and others (1985).

in 1981; and B paleochannel, discovered by drilling in 1984. Other, less well defincd, paleochannels were also discovered by drilling (fig. 2). Each paleochannel follows a unique course at a distincl elevation, whercby younger channels cut older channels (Teller and Bressler, in press). According to Moffit (1912), the bedrock floor of Tammany channel is $60 \mathrm{ft}(18 \mathrm{~m})$ above Valdes Creek where the modern canyon transects the paleochannel system. In plan view. paleochannel pattems are straight to meandering, simple, and distributary (fig. 2).

The paleochannels are fairly narrow, $V$-shaped in cross section, and as deep as $10 \mathrm{~m}$. Steep bedrock walls are primarily argillite-phyllite but locally consist of homfels and quarz monzodiorite porphyry. Paleochannel walls and floors possess a thin, slighily decomposed near-surface rind that probably formed by contacl with ground water. The floors are typically slighlly fluted by the passage of water-bome particles and bear no evidence of polishing or suriating by glacial ice (Ross, 1933).

Previous obscrvers indicated that alluvial pay gravels filling the narrow bedrock channels vary considerably. Lower gravels exhibil numerous cut-and-fill structures, and upper gravels have planar bedding (Smith, 1970a, 1981); coarse clasts up to cobble size show obvious imbrication (Bressler and others, 1985). Locally, gravels are poorly sorted (Tuck, 1938), and some sections contain thin silt or clay layers that provide barriers upon which perched gold-placers accumulated (Moffic, 1912; Bressler and others, 1985). Ross (1933) noted that boulders up $103 \mathrm{~m}$ diam are locally numcrous at the base of the channel fill and are unevenly distributed in the rest of the fill. Smith (1981) pointed out the presence of numerous, discontinuous layers of rounded and subrounded cobbles. Detritus in the pay gravel represents rock types mapped in the drainage of Valdez Crcck (Smith, 1970a, 1981); most abundant lithologies are argillite, schish quarz diorite, and a distinctive alkali gabbro. Thickness of the paleochannel gravel fill averages about $3104 \mathrm{~m}$.

Placer gold is prescnt throughout pay gravel filling the paleochannels but is concentrated in the lowest 2.6 $103 \mathrm{~m}$ within a lag of large, subrounded, granitic boulders and in underlying fractured bedrock (Moffil, 1912; Ross, 1933; Tuck, 1938: Smith, 1981). Two suites of placer nuggets are recognized: most pieces are 'oatmeal-sizcd,' bright, smooth with round edges, and flat (Yeend, 1984; Cox and others, 1989); other pieces are rough wilh small fragments of actached gangue material. In general, gold nuggets are modest in weight, averaging about $0.10 z(3.1 \mathrm{~g}$ ) (Moffil, 1912). VCMC 
Table 1. Summary of placer-gold and -silver production in Valdez Creek mining district, 1904-89 [Data from unpublished U.S. Mint records, 1904-68; Territorial Dopartment of Mines semiannual raports,

1912-58; Smich, 1933; anpublished State of Alaska questionnaires, 1978-89]

\begin{tabular}{|c|c|c|c|c|c|}
\hline Year & $\begin{array}{l}\text { Number } \\
\text { of mines }\end{array}$ & Employment & $\begin{array}{l}\text { Volume of } \\
\text { gold (oz) }\end{array}$ & $\begin{array}{l}\text { Volume of } \\
\text { silver (oz) }\end{array}$ & $\begin{array}{l}\text { Total bullion v } \\
\text { (dollars) }\end{array}$ \\
\hline $1904-6$. & 4 & 275 & 7,862 & 1,164 & 165,102 \\
\hline 1907 & 3 & -- & 1,007 & 131 & 21,147 \\
\hline 1908 & 4 & 175 & 4,837 & $67 \%$ & 101,577 \\
\hline 1909 & 3 & 100 & 2,418 & 314 & 50,778 \\
\hline 1910 & .- & -- & 1,451 & 195 & 31,000 \\
\hline 1911 & .. & -. & 1,451 & 195 & 31,000 \\
\hline 1912 & 1 & - & 387 & 50 & 8,127 \\
\hline 1913 & 1 & 25 & 290 & 24 & 6,050 \\
\hline 1914 & $i$ & 50 & 193 & 39. & 4,100 \\
\hline 1915 & 4 & .- & 1.186 & ISS & 24,906 \\
\hline 1916 & 3 & .. & 1,468 & 190 & 30,828 \\
\hline 1917 & 5 & 20 & 1,601 & 208 & 33,621 \\
\hline $191: 8$ & 4 & -- & 286 & 38 & 6,006 \\
\hline 1919 & -- & -- & 94 & 9 & 2,000 \\
\hline 1920 & -- & -- & 475 & 62 & 10,000 \\
\hline 1921 & 3 & -- & 958 & 124 & 20,100 \\
\hline 1922 & 5 & -- & 1,376 & 178 & 28,896 \\
\hline 1923 & 4 & -. & 970 & 128 & 20,370 \\
\hline 1924 & 5 & -- & 352 & 46 & 7,392 \\
\hline 1925 & 5 & - & 263 & 34 & 5,481 \\
\hline 1926 & 3 & -- & 396 & 51 & 8,316 \\
\hline 1927 & 2 & .. & 357 & 47 & 7.497 \\
\hline 1928 & 4 & .. & 693 & 89 & 14,553 \\
\hline 1929 & 3 & .- & 1,168 & 157 & 24,528 \\
\hline 1930 & 5 & 12 & 1,879 & 244 & 39.459 \\
\hline 1931 & 5 & - & 1,397 & 207 & 33,537 \\
\hline 1932 & 4 & .. & 1,148 & 149 & 24,108 \\
\hline 1933 & 2 & 20 & $195^{\mathrm{a}}$ & 26 & 4,095 \\
\hline 1934 & 3 & - & 674 & 89 & 23,594 \\
\hline 1935 & 3 & .. & 1,323 & 172 & 46,305 \\
\hline 1936 & 1 & .. & 984 & $12 B$ & 34,440 \\
\hline 1937 & 3 & - & 1,031 & 138 & 36,085 \\
\hline $1938-40$ & -- & 15 & - & .. & - \\
\hline 1941 . & 1 & 15 & 44 & 6 & 1,540 \\
\hline 1942 & 3 & 10 & 520 & 68 & 18,200 \\
\hline $1943-46$ & - & - & - & - & $\ldots$ \\
\hline 1947 & 2 & 4 & 143 & 19 & 5,005 \\
\hline 1948 & 2 & 2 & 24 & 2 & 840 \\
\hline 1949 & 2 & 2 & 26 & 3 & 900 \\
\hline 1950 & - & - & .. &.- & .- \\
\hline 1951 & 1 & 1 & 18 & 2 & 630 \\
\hline $1952-56$ & .- & .. & - & - & .. \\
\hline 1957 & 1 & 1 & 19 & 2 & 675 \\
\hline 1958 & 3 & 6 & 69 & 10 & 2,415 \\
\hline 1959 & 1 & 1 & 3 & -. & 105 \\
\hline 1960.61 & $\cdots$ & - & - & -- & $\cdots$ \\
\hline 1962 & 1 & - & 3 & -- & 105 \\
\hline $1963-76$ & -- & - & - & - & r- \\
\hline 1977 & 2 & _ & 250 & 35 & 39,000 \\
\hline $1978-83$ & - & - & - & -- & - \\
\hline 19.84 & 1 & 70 & 19.627 & 2,551 & $6,967,585$ \\
\hline 1985 & 1 & 105 & 29,833 & 3,937 & $9,606,226$ \\
\hline 1986 & 1 & 136 & 24,996 & 3,250 & $9,498,480$ \\
\hline 1987 & 1 & 150 & 21.068 & 2,823 & 9.585940 \\
\hline 1988 & 1 & 155 & 44,494 & 8,467 & $18,909,950$ \\
\hline $1989^{b}$ & 2 & 175 & 62.403 & 2568 & 22.9800500 \\
\hline TOTAL & & & 243,908 & 36201 & $78,523,094$ \\
\hline
\end{tabular}

aplacer-gold production was greater than indicated on tuble, according to Territorial Department of Mines records, but no specific figures are avialable.

bDals inclasive through Octobec 15, 1989.

$-=$ Mine records not availabte. Some minor placer gold was produced duxing periods 1938-40, 1963-76, and 1978-83; modest amounts of lodè goid have alsa been interminendy produced but are not included in table. 
data indicate that 72.6 percent of the recovered gold is between 0.97 and $5.14 \mathrm{~mm}$ diam, 22.8 percent is smaller than $0.97 \mathrm{~mm}$, and 4.7 percent is larger than $5.14 \mathrm{~mm}$ (Hughes, 1989). Gold recovered from placers in the Valdez Creek drainage has a remarkably consistent fineness of 852 (Smith, 1941; Eakins and others, 1985: Bundtzen and others, 1986, 1987), although two exceptions to this consistency are placer gold recovered from Lucky Gulch (fineness $=828$ ) and (rom Tammany channel near Timberline Creek (fineness $=844$ ) (Jerry O'Connor, written commun., 1989; sheet 1). In addition to gold, placer concentratcs typically contain abundant pink garnet, green and brown hornblendes, magnetite, and pyrite; minor zircon, apatite, staurolite, sillimanite, kyanite, and biotite; and rare yellow garnet, epidote, hypersthene, rutile, and probably monazite (Mofrit, 1912; Ross, 1933). Concentrates collected by Wimmler (1925, p. 70-71) from White Creek (sheet 1) contained hessite (a silver telluride), native bismuth, arsenic, and base-metal sulfides; goldfieldite has becn identified on Timberline Creek (Smith, 1981). So far, these minerals from White and Timberline Creeks have not been identified in A paleochannel gravels currently mined by VCMC.

In the thick section above the pay-gravel fill of the bedrock paleochannels, sediments are related to stream activity or directly and indireclly to glaciation (Moffich 1912; Ross, 1933). Although Smith (1970a, 1981) observed that the top of the section includes outwash gravels overlain by till containing numerous erratic boulders, no detailed descriptions of the upper section are published.

\section{OBSERVATIONS IN VCM PIT A5}

Our studies in VCM have been brief, and limited to deposits in and overlying paleochanncl A. Bundtzen studied sediments in pit $A 3$ on November 21, 1986, and both of us sampled organic deposits at the bottom of pit A5 on August 5, 1988, shortly after a fragmented proboscidean lusk was removed from pay gravel. We both made later lours of pit A6 in the spring and summer of 1989. Our observations of the stratigraphy in the southeasterm wall of pit A5 are supplemented by results of subsequent radiocarbon dating and pollen analysis of sediment samples we collected and by an unpublished radiocarbon dace (fig. 3, sample QL-4278) kindly provided by John Cook (oral commun., 1989).

Figure 3 summarizes, in a general way, the section exposed in the southeastern wall of pit A5 on August 5 , 1988. Subrounded to rounded granitic boulders of paleochannel $A$ were concentrated on argillite-phyllite bedrock (fig. 3, unit 1) and scattered throughout the 4.5m-thick pay gravel (fig. 3, unit 2; fig. 4). A radiocarbon date of greater than 32,310 ys B.P. (fig. 3, sample BETA-18870) was determined for shrub twigs and branch fragments collected on November 21, 1986, from a correlative lower pay gravel in pit A3. A $1.2-\mathrm{m}$ length of an $18-\mathrm{cm}$-diam, broken tusk, probably of a mammoth (Mammuthus), was collected 3 m below the top of pay gravel in pit A5 on August 3, 1988; its in-situ location was shown to us by the worker who found it A small amount of collagen extracted from part of this tusk, which is archived in a deep freeze at the University of Alaska Fairbanks Museum, was dated by standard methodology at $39,900+2,800-2,100$ yr B.P. (fig. 3. sample QL-4278) at the University of Washington (Minze Stuiver, written commun., 1989).

Discussions with VCMC geologists indicate that they have not seen nor recognized evidence of significant soil development within the pay gravel. However, at the top of pay gravel there was, at least locally, a discontinuous lag of cobbles and boulders (fig. 3, unit 3), which, although the lag did not exhibit evidence of significant associated soil development, represents an unconformity. A $0.3-\mathrm{m}$-thick, felted and highly compressed peat (fig. 3, unit 4) covered the cobble-boulder lag at the locality we visited, but discussions with VCMC geologists indicate that it is present only rarely elsewhere. This peat was subsequently dated at greater than 40,000 yr B.P. (fig. 3, sample GX-14432).

Overlying the compressed peat was about $6 \mathrm{~m}$ of cross-bedded fine sand (fig. 3, unit 5), which we attribute to fan-delt deposition in a former lake. This sand was overlain by about $9 \mathrm{~m}$ of medium- to thickbedded cobbly pebble gravel (fig. 3, unit 6) that conlained granitic clasts.

The center of the section was dominated by two thick layers of thin-bedded (varved) silty fine sand (fig. 3, units 8 and 10; fig. 5) that were separated by a discontinuous tonguc of iron-oxide-stained cobbly pebble gravel (fig. 3, unit 9). The lowest $5 \mathrm{~cm}$ of the 8.5-m-thick lower sand was composed of a single layer of silty, organic fine sand (fig. 3, unit 7; fig. 6) that was dated at $25,900+3,600-1,900$ yr B.P. (fig. 3, sample GX-14433). A 4.5-kg sample of varved lacustrine silty fine sand was previously collected for pollen analysis (sable 2) from pit $\mathrm{A} 3$ at a location $20 \mathrm{~m}$ stratigraphically above a radiocarbon sample (BETA-18870) in pay gravel of paleochannel $A$; we consider this sample location to be equivalent to the lower part of the middle thick sand in pit A5 (fig. 3, unit 8).

Discussions with VCMC geologists and brief inspection of their unpublished goologic information indicate that the thin interformational gravel tongue (fig. 3, unit 9) separating the thick fine-sand units is present elsewhere in VCM but is discontinuous. Above the gravel tongue, the upper thin-bedded silty fine sand 


\section{RADIOCARBON AGE (LABORATORY NO.) \\ SCHEMATIC SECTION}

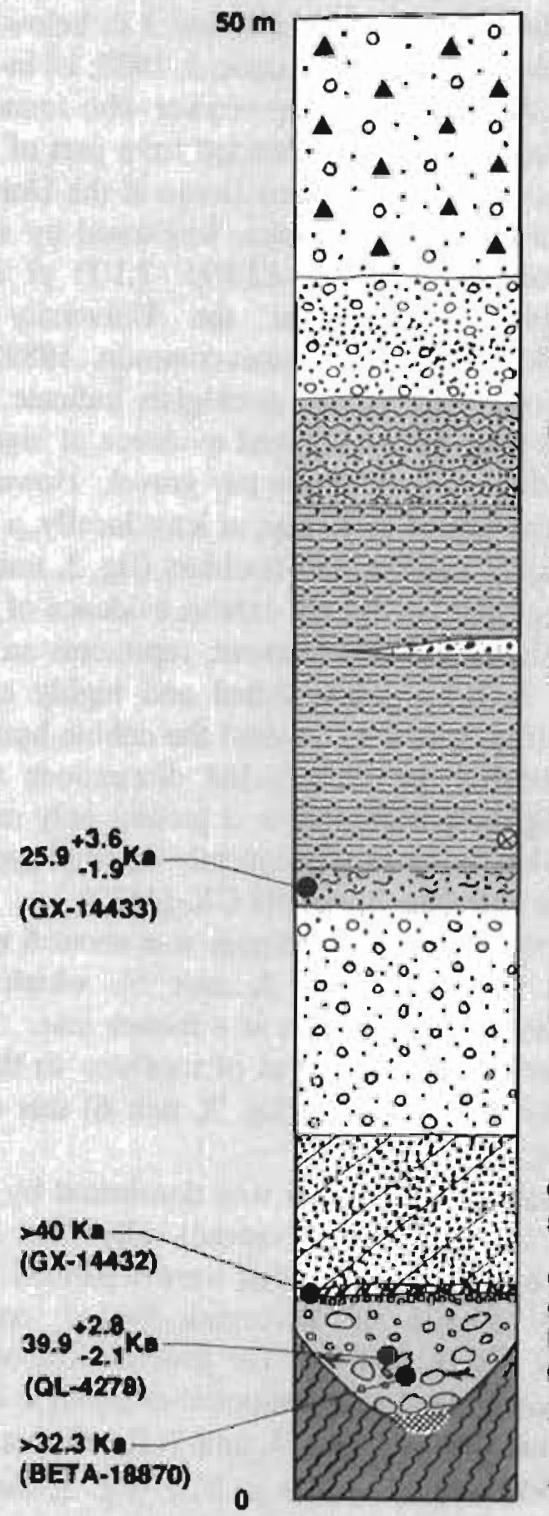

GEOLOGIC UNIT

Surtace soll (15)

Thin loess (14)

Till (13)

Fluvial \& ictagnation gravels and sands (12)

Rippled lacustrine sand (i1)

Upper thin-bedded (varved) Lacusirine silty fine sand (10)

Stained fluvial cobbly Dobble gravel longue (9)

\section{Lower thin-bedded} (varved) lacustrine silty line sand $(\theta)$

Basal organic fine sand (7)

Fluvial cobbly pobble gravel (6)

\section{Cross-bodded lan-della} sand (5)

\section{Compressed peat (4)} Cobbly boukder lag (3) Fluvial bouldery cobble gravel (2)

Basel boulder concentraton (1)

Argiline-phyllite bedrock
INFEARED EVENT INFEARED AGE

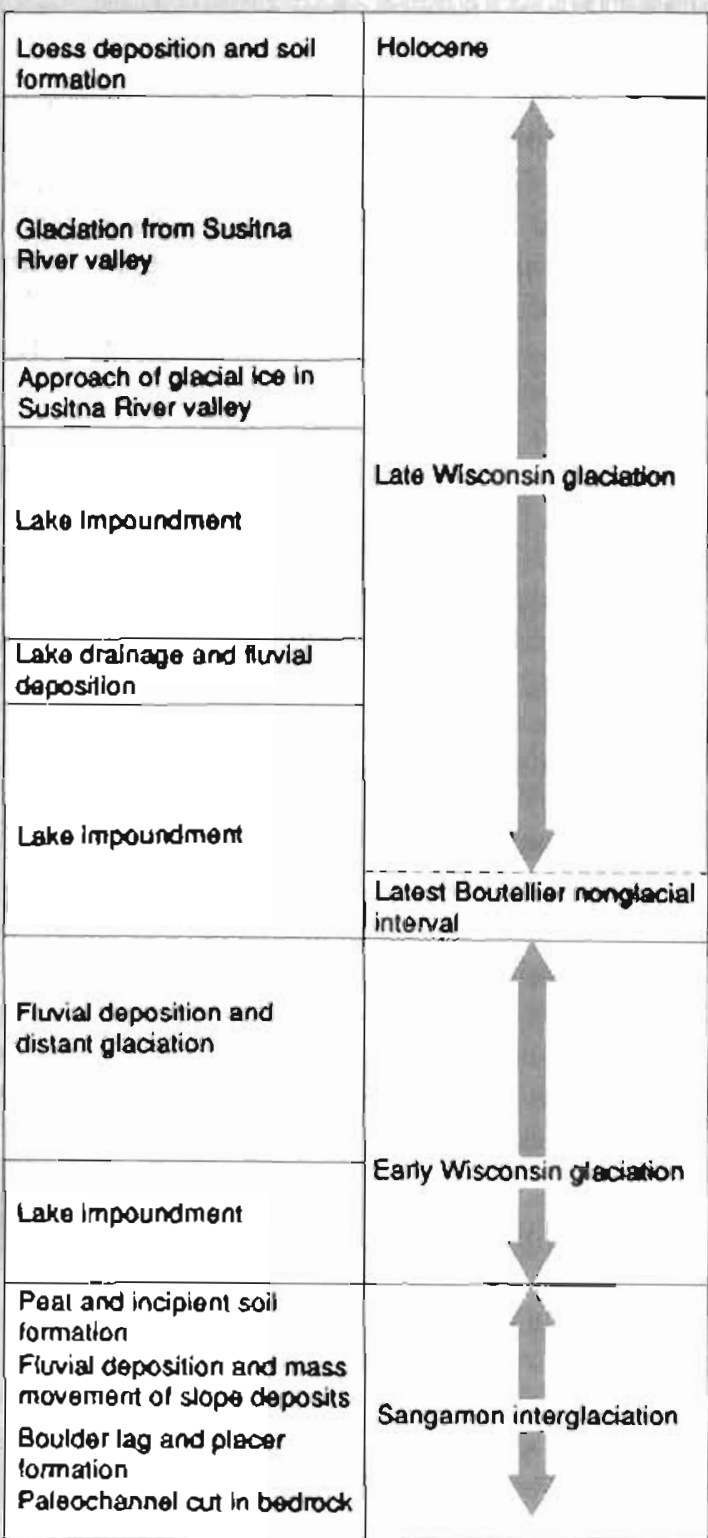

- Radiocarbon sample

- Pollen sample

Gold placor
Tusk Iragment (Mammuthus?)

$\ll$ Shrub branches and iwlgs

Figure 3. Generalized stratigraphic section exposed August 5, 1988, in pil AS, Valdez Creek Mine, related 10 lute Pleistocene events. Pollen sample in unil 8 and radiocarbon sample BETA-18870 were collected in pil A3 on November 21, 1986. from geologic units equivalem to those shown in this section. Numbers in parentheses in geologic-unir column are used in texi for ready rejerence. 


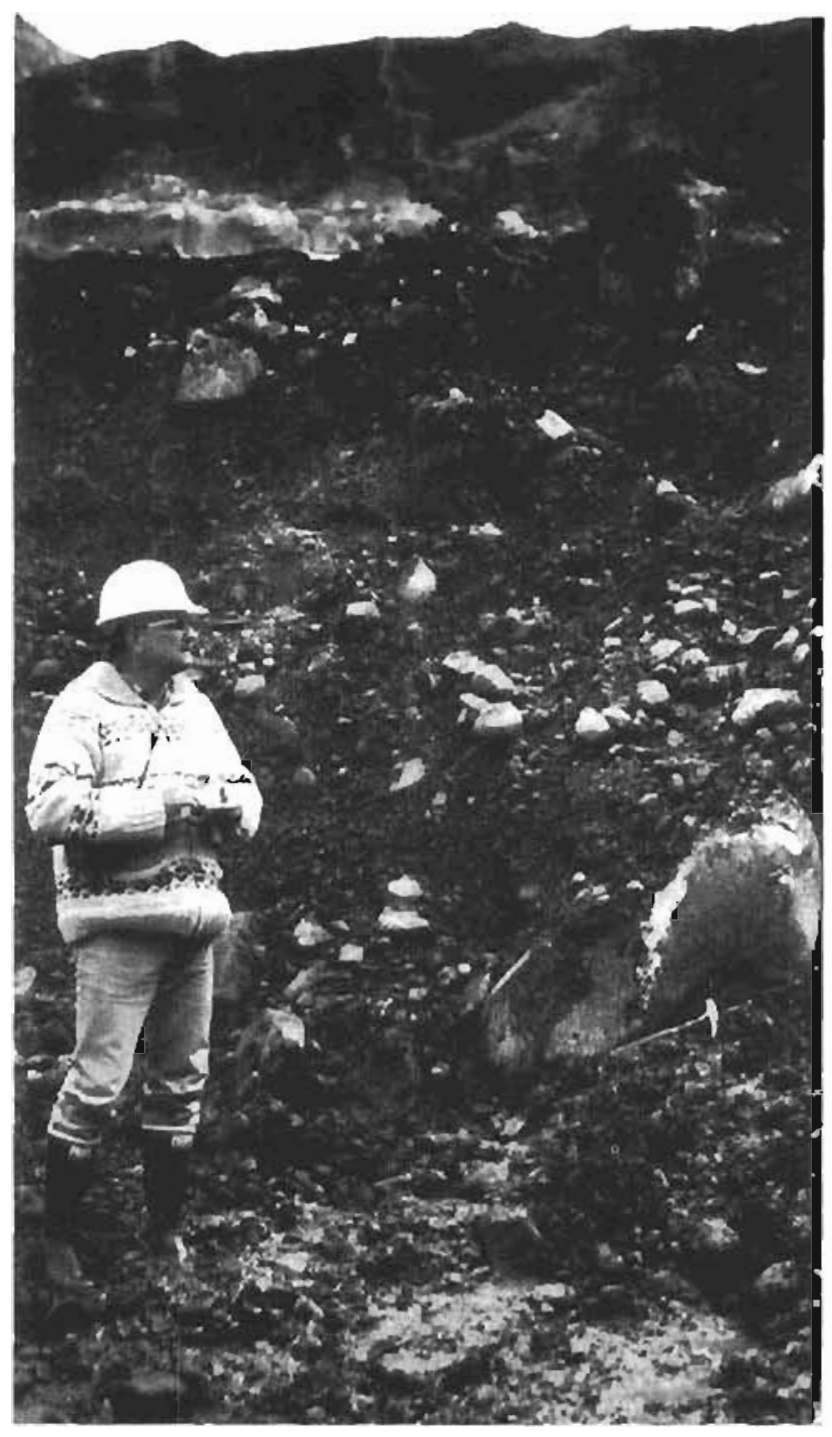

Figure 4. Large granitic erratics in pay gravel at bollom of pil AS, Valdez Creek Mine. Nole rock liammer for scale. Pholograph taken August 5, 1988.

(fig. 3, unit 10) was about $8 \mathrm{~m}$ thick. The upper $3.6 \mathrm{~m}$ of this sand in pit AS (fig. 3, unit 11) were distinculy rippled and exhibited no obvious evidence for postdeposilional deformation by ice shoving or glacier thrusting.

Disconformably overlying the thick sand section was a 4.5-m-thick complex unit of Ruvial and ice-contact deposits composed of planar and cross-bedded cobbly pebble gravels interlayered and incrfingerce with sand layers and longues (fig. 3, unit 12). Capping the whole section was an 8-m-thick till complex bearing a 30- to 40-cm-thick cover of locss (fig. 3, units 13 and 14). A moderately developed soil prolile (fig. 3, unit 15) had formed in both the loess and the upper part of the uill.

\section{SUMMARY OF EVENTS DOCUMENTED IN PIT A5}

The stratigraphic section in VCM pil A5 (fig. 3) provides evidence for the ages of palcochannel $A$ and associatci gold placers and for at lcast three glaciations.

\section{FORMATYON OF PALEOCHANNEL A AND ASSOCIATED DEPOSITS}

The first Quaternary event direcly documented in the scclion we observed in pit A5 is the cutling of palcochannel A to a local depth of about $4 \mathrm{~m}$ into the argillite-phyllite bedrock. The slcep-walled, V-shaped channel cross section and the concentration of large boulders in the channel boutom are cuidence lor vigorous streamflow during channel incision and placer formation. Numcrous meanders, anabranches, and straight reaches in the paleochannel patterns indicate that Valdez Creek had a variable morphology prior 10 lowering of local basc levcl. Incision cycles of ancestral Valdez. Creck were probably triggered by deglaciation (Smith, 1981). Most likely, Iocal cycles of crosion and placer formation began at the mouth of Valdez Creek simultaneously with incision of the ancestral Susitna River into its alluvial fill during nonglacial inccrvals. Once initiated, the wave of downcutuing and concentration of large boulders and heavy minerals probably progressed rapidly up Valde\% Crcek, following existing channcls, whether straight, mcandering, or brajded.

We attributc development of the thin surface layer of decomposed bedrock in the channel walls and floor to contact with chemically active ground water after burial of bedrock and not to pedological processes aclive at the channel surface prior to formation of the basal boulder lag (fig. 3, unit I) and simultaneous deposition of rich bedrock placers. Expcrimencal studics undertaken by Schumm (1977) and his associates (Schumm and ouhers, 1987) demonstraled that bedrock lags and bedrock placers typically form together by reworking of previous deposits that contain placer minerals. Cheney and Patuon (1967) concluded that placers on bedrock beneath thick alluvial fill develop during infrequent floods of very large (unusual) magnitude when most of the channel fill is scoured out and all that is left are the largest clasts and heavymineral concentrates.

Lack of recognized evidence for weadhering pronles in pay gravel burying the basal boulder lag and bedrock placers and filling palcochannel A (fig. 3 , unit 2) implies that paleochannel A filled with gravel soon aficr it was cut. The presence of discontinuous layers of cobbles, scallered nests of boulders. and zones 


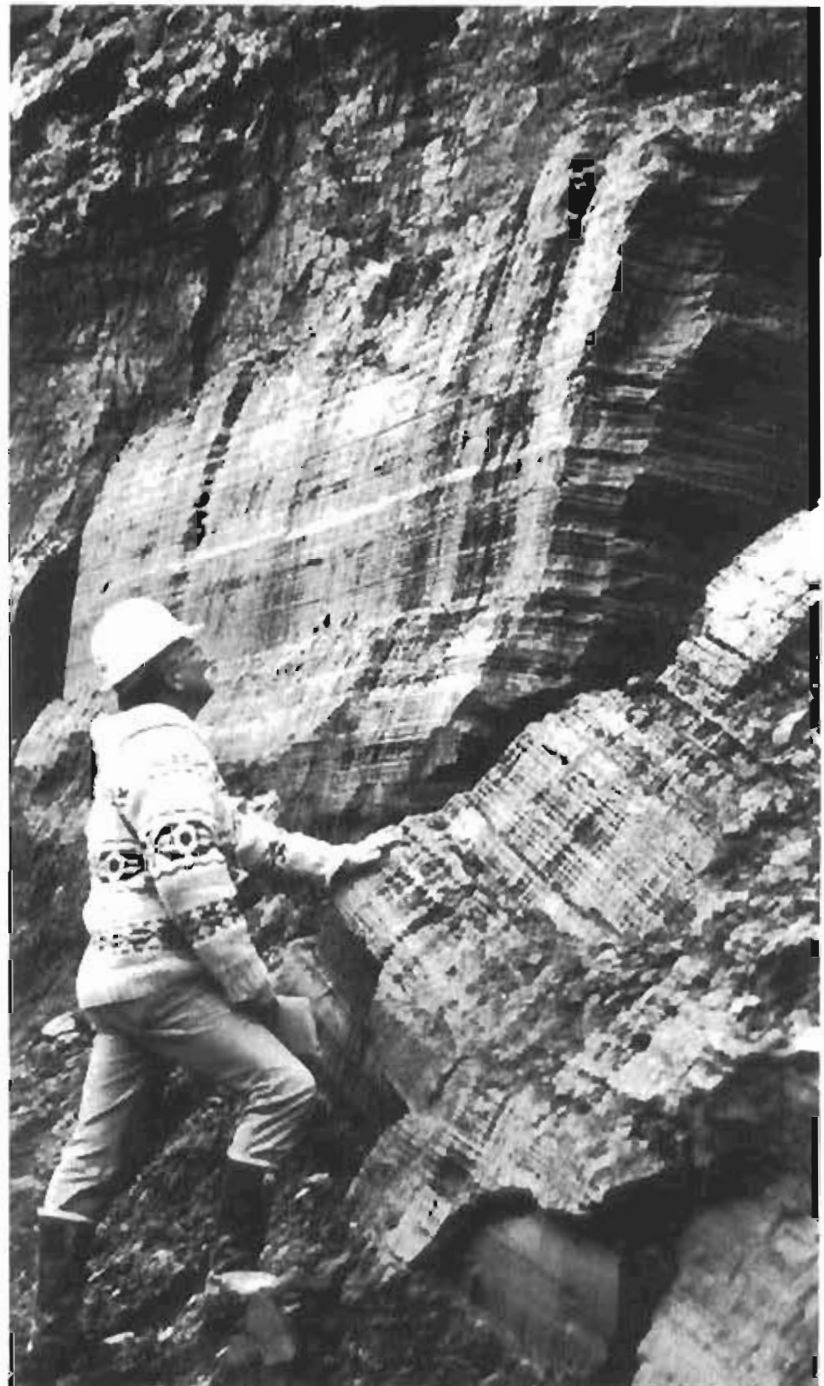

Figure 5. Thin-bedded (varved) silly fine sand in lower part of thick lacustrine section, pit A5. Valdez Creek Mine. Nole light-loned lephra layer. Pholograph aken August 5, 1988.

of poorly soried sediment (hig. 4) in pay gravel records episodic floods and mass movement of slope deposits into the channel during gravel oeposition. We agrce with Smith (1970a, 1981) that clast lithologies represent oulcrops in the Valdez Creek drainage basin and indicale that the basal boulder lag and overlying pay gravel probably came from the Valdez Creck basin.

The boulder lag at the top of pay gravel (fig. 3. unit 3) clearly documents a pcriod of nondeposilion and winnowing late in the gravel-dcposition phase, but this lag probably does nol have much lime signilicance because it is not widespread in VCM and there is no soil prolile associated with it. The well-compressed peal (Fig. 3. unil 4) capping unit 3 records a period of high water Icvel (shallow water table) and at least local thick accumulation of paludal vegetation on the gravel channel fill.

On the basis of several lines of evidence, none of which are conclusive, we propose a Sangamon ${ }^{2}$ age for cuiting of palecchannel $A$ and formation of its associated bedrock placers. First, the large granilic boulders in the basal bag of palcochanncl $A$ and the boulders scaltercd throughout pay gravel werc probably derived from the drainage of Valdez Creck. Their compositions, sixcs, and shapes are consisent with glacial erratics brought in by ice that originated in the upper Valdez Creek drainage. We propose that these boulders were carried into the channel by mass movements-jncluding debris flows and solifluction--Lhat rctransponed till deposiled in lower Valdez Croek valley during lllinoian ume. Culling of palcochannel $A$ and simultancous formation of the basal boulder lag with its associatcd bedrock placers postdate the Illinoian glaciation.

Second, there is evidence provided by the amoun and lype of woody material found in the gravelly fill of palcochanncl A. Elsewhere in interior Alaska, Sangamon-age deposits contain considerablc wood, including well-prescrved remains of large trees (Pèwd and oliers. 1989). However, the absence of tree remains in pay gravel of palcochannel $A$ and the presence of only shrub remains do not rule oul a Sangamon age for palcochanncl A bccausc current VCMC opcrations at $2,800 \mathrm{ft}$ $(850 \mathrm{~m})$ elcvalion are just above modern treeline, where the locality was probably situated in Sangamon time. Further, the vigorous depositional environment of the gravęls was probably nol conducive to preservation of wood. The infinite radiocarbon age for slirub iwigs and branches from pay gravel (rig. 3, sample BETA-18870) is inconclusive in that it sets only a minimum limit of 32,310 yr B.P. for the age of pay gravel.

Third, there is evidence provided by the broken proboscidean lusk found $3 \mathrm{~m}$ bclow the top of pay gravel (fig. 3). We believe that the finice average agc of 39,900 yг B.P. (fig. 3, sample GL-4278) for this usk is spuriously young for several reasons. First, it boes not agree with the two infinite dates for wood and peat dhat are stratigraphically close to the tusk. Sccond, tho amount of collagen daled was very small and the resultant reydings upon which the 39,900-yr average is based ane highly variable, as documented by the large sigma

\footnotetext{
2Provisional ages are assigned 10 informal Quaternary time tenns as follows: Holocene $=$ younger than $9,500 \mathrm{yr}$ ago; lute Wisconsin glaciation $=9,500$ 10 25,000 yr ago: Boulellicr interstadial $=25,000$ to 65,000 yr ago: curly Wisconsin glaciation $=65,000$ to $122,0(x)$ yr ago: Sangamon interglacialion $=122,000$ 10 $132,000 \mathrm{yr}$ ago: Dlinoian glaciation $=132,000$ to 302,000 yr ilgu: pre-lllinosiun tine $=302,000$ 10 $1,650,000$ yr ago (modified from Ters Isrink, 1983; Richmond and Fullerton, 1986).
} 


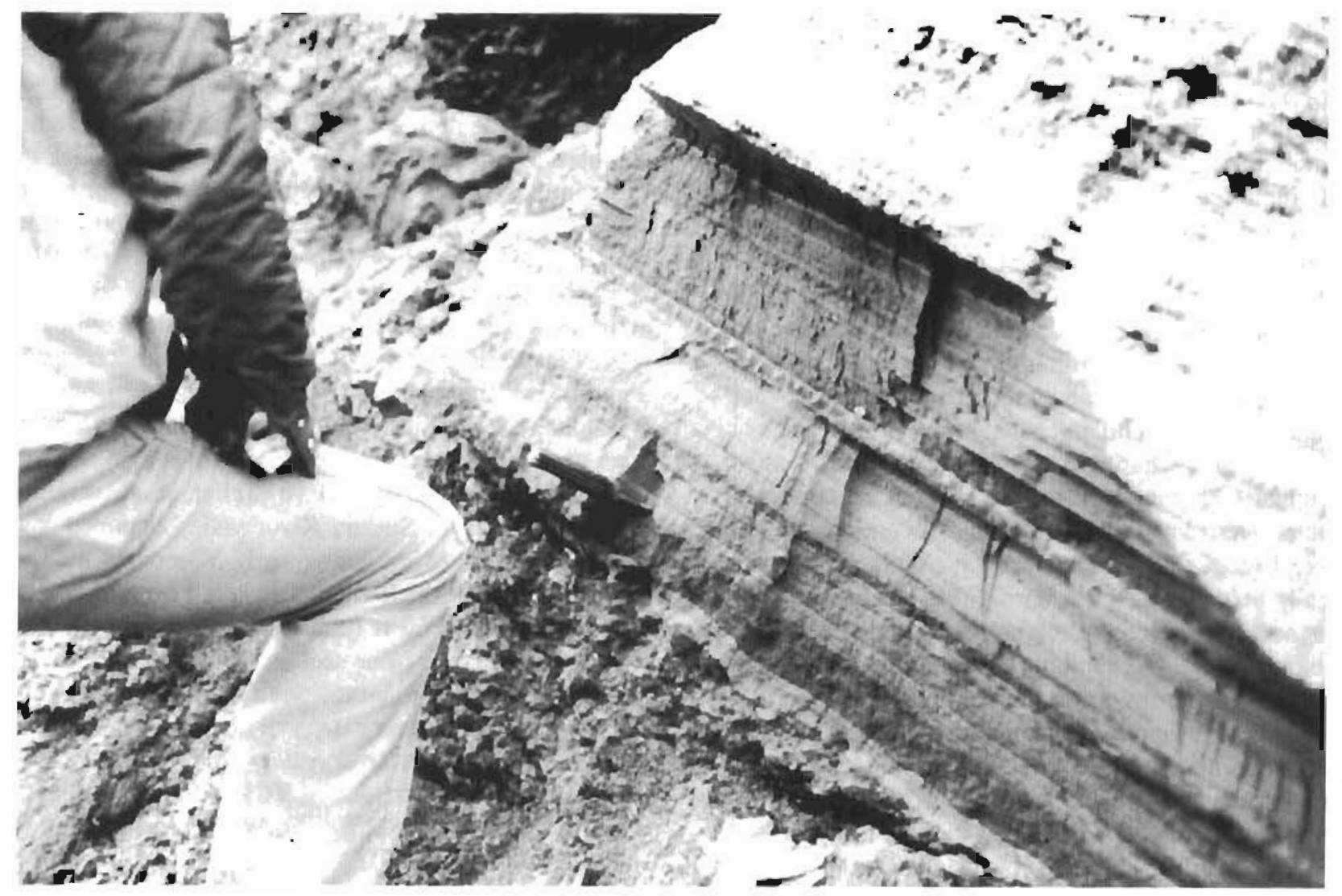

Figure 6. Medium-gray-brown organic fine sand at base of lower thick, lacustrine silty fine sand, pil AS, Valdez Creek Mine. Note knife handle (10 cm long) for scale. Pholograph taken August 5, 1988.

Table 2. Spore and pollen from silly fine sand of lower part of varved lacustrine section, pil A3, Valdez Creek Mine

[Plants identified by T.A. Ager, U.S. Gcological Survey, Reslon, Ving inin]

Type or

plant remains

Spores

Policn

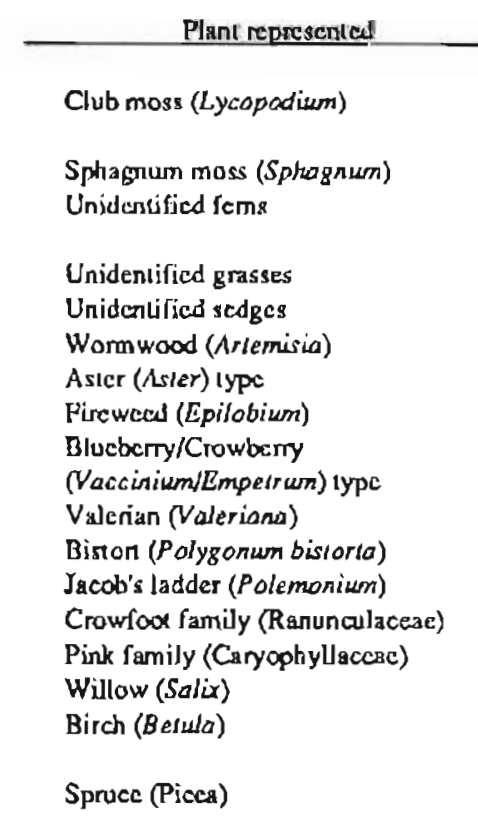

\author{
Comment \\ Most abundant spores, three spocics \\ idersisicd \\ Few spores present
}

\author{
Small amount of pollen \\ Very small amount of pollen; may be dwarf \\ or resin birch \\ Some well-preserved pollen
}


values of $+2,800$ and $-2,100$ yr (Minze Stuiver, written commun., 1989). Third, the chalky and permineralized appearance of the tusk indicates that it is considerably altcred from its original character and that significant contamination exists. A radiocarbon date of $39,900 \mathrm{yr}$ B.P. indicales that only 0.7 percent active carbon is prescnt in the sample (Minze Stuiver, written commun., 1989). Hence, introduction of cven small amounts of radioactive (younger) carbon could change an infinite radiocarbon age 10 an anomalously young finite age.

Fourth, the 0.3-m-thick, compressed peat at the top of pay gravel (fig. 3, unit 4) records at least local accumulation of hydrophilic vegetation on the paleochannel fill, probably during a rclativcly warm, moist, nonglacial climate. If $0.3 \mathrm{~m}$ of peat remains after glacial overriding, dewatering, and severe compaction, several mcicrs of vegesal matter probably accumulated locally before subscquent burial. The peat found in the channel section could represent scveral millenia of gcologic time. A similarly compressed peat of like thickness that crops out in the sea bluff at the mouth of Goose Bay in upper Cook Inlet is almost certainly of Sangamon age and pollen in that peat documents progressive development of a spruce-hardwood woodland much like the modern woodland in the Goose Bay area (Reger, unpublished data). Unforwnatcly, at this time we have no pollen data from the compressed peat in VCM 10 verify similar forest development.

Fifh, there is direct and indirect stratigraphic evidence preserved in pit A5 for at least two glacialions of Wisconsin age in the VCM area.

An altemative age for paleochannel $A$ and its associated deposits is early middle Wisconsin interstadial (that part older than 40,000 yr). In our opinion, the presence of the thick compressed peat and the unconformity (local cobble-boulder lag) at the top of pay gravel and evidence for at least two glaciations of Wisconsin age in the overlying deposits argue against this possibility.

\section{POST.PLACER EVENTS IN PIT A5 AREA}

\section{INITIAL LAKE FORMATION AND OUTWASH DEPOSITION}

After formation of the cobble-boulder lag and deposition of peal at the top of pay gravel (fig. 3, units 3 and 4) during the Sangamon interglaciation, about $6 \mathrm{~m}$ of cross-bedded fine sand (fig. 3, unit 5) was deposited in the area of our pit A5 scction during early Wisconsin lime. We propose that this sand was deposited as a fan dela in a boty of standing water (probably of lake size) that was impounded in lower Valdez Creek valley. This impoundment occurred probably because sedimentation by Valdez Creek could not keep pace with an abrupt rise in local base level that was a direct or indirect consequence of glaciation in Susitna River valley (fig. 1; sheet 1). The abrupt rise in base level could have been caused by physical blocking of lower Valdez Creek by a glacier advancing down Susitna River valley or by very rapid aggradation of the Susitna River nood plain to which Valdez Creck was graded.

Although we have not observed evidence of a former glacier dam in Susitna River valley during our brief inspections of the VCM deposit, other workers obscrved stratigraphic changes close to the mouth of Valdez Creek that could have resulted from the presence of a glacier (of post-pay-gravel age) in ncarby Susitna River valley (Steve Teller, oral commun., 1989), If ice in Susilna River valley danmed lower Valdez Creek valley during early Wisconsin time, the glacier was not thick enough wo reach a modem elevation of about $2,800 \mathrm{ft}(850 \mathrm{~m})$, the approximatc elcvation of the base of our section, because it left no evidence of deposition or erosion in pit A5; it was ccrtainly much thinner and less extensive than the late Wisconsin glacier in Susitna River valley that extended $33 \mathrm{~km}$ downvalley from the site of VCM to the Hatchet Lake moraine (Smith. 1981, fig. 29; Williams and Galloway. 1986; Williams, 1989).

Less likely would be damming of lower Valdez Crock by rapid aggradation of the Susitna River hood plain, an indirect response to glaciation in the headwaters of Susilna River. Numerous llood-plainmarginal lakes of the rapidly aggrading, proglacial middle Tanana River (Pèwè and Reger, 1983a), such as Harding, Quartz, and Birch Lakes, are modem analogs to this possible condition.

Following deposition of the fan-delta sand, about $9 \mathrm{~m}$ of cobbly pebble gravel (fig. 3, unit 6) was deposited in the pit AS area. This gravel represents outwash deposition downstream from alpine glaciers somewhere in Valdez Creek valley.

Our evidence for an early Wisconsin age for the fan-delta sand (unit 5) and outwash gravel (unit 6) is the suspected Sangamon age of the underlying deposits and the date of $25,900+3,600-1,900$ yr B.P. (fig. 3, sample GX-14433) for the organic fine sand on top of the gravel.

\section{SUBSEQUENT LAKE IMPOUNDMENTS}

The next major episode documented in pit AS is an extended time of lake impoundment of lower Valdez Creek valley, recorded by units 7 through 11 (fig. 3). Evidence for initial ponding of a clear-water stream is the presence of the 5-cm-thick organic finc sand (fig. 3, unit 7) on top of the valley-train gravel (fig. 3, unit 6). 
Soon after its formation, this clear-water pond or lake was apparently inundated by silty lake waters in which silty fine sand (fig. 3, urit 8) was deposited.

A qualitative survey for plant microfossils in the sediment sample collected near the bottom of the lacustrine section in pit A3 (fig. 3) revealed a surprising abundance of pollen and spores (table 2) that are indicative of the local vegetation during the early history of the lake. These microscopic plant remains are characteristic of an herb-dominaled tundra with interspersed low willow and birch shrubs (Tom Ager, writtcn commun., 1987). The presence of small amounts of well-preserved spruce pollen probably indicates that spruce was present in the region.

After deposition of at least $8.5 \mathrm{~m}$ of silty fine sand in the lake, drainage occurred (probably suddenly), as recorded by the gravel tongue (fig. 3, unit 9), possibly represcnting distal outwash, in the middle of the lacustrine section in pit A5. The thin, discontinuous nature of the gravel and the apparent immediate resumption of lacustrine-sand deposition at the site are evidence that lake drainage was very brief and that the blocking body was soon replaced. We speculate that rapid lake drainage could have resulted from catastrophic failure of an ice dam (Post and Mayo, 1971).

Following redamming of lower Valdez Creek and deposition of at least $4.4 \mathrm{~m}$ of silty fine sand (fig. 3 , unit 10), lake depth became sufficiently shallow that oscillating sufface waves began imposing a rippled character to the upper $3.6 \mathrm{~m}$ of bottom sand (fig. 3, unit 11) as the final lake fill was deposited.

Evidence for a latest Boutellier or late Wisconsin age, or both, for the middle (thick lacustrine) section in pit A5 (fig. 3, units 7 through 11) includes the date of $25,900+3,600-1,900$ yr B.P. for the basal part of the section (fig. 3, sample GX-14433), the pollen record, and the inferred damming of lower Valdez Creek by a glacier advancing down Susitna River valley. The large sigma values for sample GX-14433 are due to the small amount of datable organic matter recovered from the fine sand (fig. 3, unit 7). These values make the average date of $25,900 \mathrm{yr}$ B.P. slightly suspect in our opinion, but this date and the inferred history documented by the upper part of the pit A5 section complement results elsewhere in eastern Beringia (Hopkins, 1967; Hopkins and others, 1982; Kontrimavichus, 1984; Ritchie, 1984; Carter and others, 1989). Nonetheless, because the sigma values are large, others may consider this sample to actually be older than the Iimit of standard radiocarbon dating (Dave Hopkins, oral commun., 1989).

Although sediments between dated or inferred early and late Wisconsin deposits in Beringia have been dated between about 25,000 yr B.P. and the maximum range of radiocarbon dating by standard (not enriched) techniques (as much as 49,000 yr B.P.) (table 3), many of these results undoubtedly date deposits of waxing and waning glacial phases and not just the mid-Wisconsin interstadial complex. Most radiocarbon dates for the Boutellier nonglacial interval cluster from about 25,000 to 35,000 yr B.P. during the last half of the mid-Wisconsin interstade (Schweger and Janssens, 1980; Hamilton and Robinson, 1988). A local exception, based on radiocarbon and amino-acid (wood) dates, is suggested by Connor (1983), who estimated that the Boutcllier nonglacial interval began as early as 65,000 yr ago southeast of the Valdez Creek area in the Copper River basin. Thus, the radiocarbon evidence in pit A5 supports an age of latest Boutellier or early late Wisconsin for the initiation of lake impoundment.

We assert that well-preserved spruce pollen in the lower lacustrine section of pit A3 (table 2) indicates the presence of spruce in the region and also implies a latest Boutellier or early late Wisconsin age for the base of the lacustrine scction. Palynologists have similarly documented the widespread presence of spruce in mid-Wisconsin Beringian sediments (Ramplon, 1971; Matchews, 1974; Schweger and Janssens, 1980; Connor, 1983, 1984; Heusser, 1983; Ager and Brubaker, 1985). In contrast, deposits that are clearly late Wisconsin in age typically contain little or no spruce pollen throughout interior Beringia, except for a spruce refugium in northwestem Canada; significant spruce pollen begins to reappear in spectra across this broad region only after about 9,500 yr ago (Ager, 1982, 1983, 1989; Matthcws, 1982; Ritchie and Cwynar, 1982; Schweger, 1982; Ritchie, 1984; Ager and Brubaker, 1985). A possible exception is pollen evidence for an open, low-growing spruce forest with patches of shrubs and tundra that persisted into late Wisconsin time southeast of Valdez Croek in the eastem Copper River basin (Connor, 1983).

Our strongest evidence for a late Wisconsin age for most of the thick lacustrine section in pit A5 is physiographic and deductive in nature. Clearly, lower Valdez Creek was dammed for a significant time by a blocking body that occupied the adjoining Susitna River valley. Evidence for sudden drainage of the impounded lake, quickly followed by refilling, implies that the blocking body was a glacier that originated in the cen. tral Alaska Range to the north. To block lower Valdez Creek valley, this glacier must have flowed southward from its source area to a terminal position at least $25 \mathrm{~km}$ beyond the present terminus of the nearest large valley glacier in the Alaska Range (West Fork Glacier; fig. 1). Conditions causing glacial expansion of this magnitude existed during late Wisconsin time in the central Alaska Range (Pèwè, 1975; Woodward-Clyde Consultants, 
Table 3. Published radiocarbon dates of middle Wisconsin sediments from Alaska and Yuton Territory

\begin{tabular}{|c|c|c|c|c|}
\hline Area & $\begin{array}{l}\text { Radiocarbon date, } \\
\text { in ys B.P. } \\
\text { (Caboratory no. }\end{array}$ & Material dated & Conment & Reference \\
\hline $\begin{array}{l}\text { Sonth Fork Kuskokusim } \\
\text { River, Farewell area }\end{array}$ & $\begin{array}{l}34,340 \pm 940 \\
\text { (BETA-4222) }\end{array}$ & $\begin{array}{l}\text { Organic layer at base of late } \\
\text { Wisconsin loess }\end{array}$ & -. & Kine and Bundtzer (1986, p. 131) \\
\hline Big River, Farewell area & $\begin{array}{l}38,500 \pm 980 \\
\text { (BETA-4221) }\end{array}$ & Forest bed in loess & Dates earty loess rain in Farewell area & Do. \\
\hline \multirow[t]{2}{*}{$\begin{array}{l}\text { Sanford River, norlheastem } \\
\text { Copper River basirt }\end{array}$} & $\begin{array}{l}28,300 \pm 1,000 \\
(\mathrm{~W}-1343)\end{array}$ & Organic material in bluff & $\begin{array}{l}\text { Dates interval wher proglacial lake in } \\
\text { Copper River basin was at low level } \\
\text { (about } 655 \mathrm{~m} \text { ) }\end{array}$ & Ferrians and Nichols (1965, p. 100) \\
\hline & $\begin{array}{l}31,300 \pm 1,000 \\
(\mathrm{~W}-343)\end{array}$ & do. & do & Do. \\
\hline \multirow[t]{3}{*}{$\begin{array}{l}\text { Tyone River bluff, north- } \\
\text { western Copper River basin }\end{array}$} & $\begin{array}{r}29,450 \pm 610 \\
(\mathrm{DIC}-1819)\end{array}$ & $\begin{array}{l}\text { Collagen from proboscidean bone in } \\
\text { nonglacial fluvial gravel (unit 3) }\end{array}$ & -- & Thorson and ochers (1981) \\
\hline & $31,070 \begin{array}{r}+860 \\
-960\end{array}$ & $\begin{array}{l}\text { Small twigs from channel fill in fluvial } \\
\text { sand of reworked nearshor lacustrine }\end{array}$ & - & Do. \\
\hline & (DIC-1862) & of detaic deposits (upper unit 2) & & \\
\hline \multirow[t]{2}{*}{ Lower Nelchina River } & $\begin{array}{l}>38,000 \\
(\mathrm{~W}-842)\end{array}$ & $\begin{array}{l}\text { Organic material fron locality D beneth } \\
\text { drift of last major glaciation and } \\
\text { above advance oulwash }\end{array}$ & - & Williams and Galloway (1986) \\
\hline & $\begin{array}{l}>38,000 \\
(W-295)\end{array}$ & $\begin{array}{l}\text { Peat and woody debris from locality } E \text { in } \\
\text { upper lacustrine deposits beneath } \\
\text { advance ourwash and drif of last } \\
\text { major glaciation }\end{array}$ & - & Do. \\
\hline Northen Talkeana Moutains & $\begin{array}{c}30.700+260 \\
-1,230 \\
\text { (DIC-1859) }\end{array}$ & $\begin{array}{l}\text { Interstadial sediments benesth late } \\
\text { Wisconsin drift }\end{array}$ & - & Thorson and others (1981) \\
\hline $\begin{array}{l}\text { Upper Brushkana Creek, } \\
\text { southoentral Alaska Range }\end{array}$ & $\begin{array}{l}>37,000 \\
\quad(6 \times-8057)\end{array}$ & $\begin{array}{l}\text { Wood obips in lacustrine fine sand } \\
5.5 \mathrm{~m} \text { above till }\end{array}$ & - & $\begin{array}{l}\text { Woodward-Clyde Consultants } \\
\text { (1982, table 3-2) }\end{array}$ \\
\hline $\begin{array}{l}\text { Liute Delta River, north- } \\
\text { central Alaska Range }\end{array}$ & $\begin{array}{c}24,900 \pm 200 \\
(Q L-1367)\end{array}$ & Palcosol benenth outwash & - & Ten Brink (1983, table 1) \\
\hline $\begin{array}{l}\text { Delus Creek, sorthcentral } \\
\text { Alaska Rage }\end{array}$ & $\begin{array}{c}-70,000 \\
(1-10679)\end{array}$ & Organic material above Healy ourwash & - & Do. \\
\hline $\begin{array}{l}\text { Toklat River, norhecentral } \\
\text { Alaska Range }\end{array}$ & $\begin{array}{l}28.750 \pm 400 \\
(1+10,534)\end{array}$ & Organic material above Healy cutwash & - & Ten Brink (1983, tabte 1) \\
\hline $\begin{array}{l}\text { Sushana River, northoentral } \\
\text { Alaska Range }\end{array}$ & $\begin{array}{c}43,600 \pm 700 \\
(\mathrm{QL}-1370)\end{array}$ & do. & - & Do. \\
\hline $\begin{array}{l}\text { Gerstle River, northeastem } \\
\text { Alaska Range }\end{array}$ & $\begin{array}{c}25,300 \pm 950 \\
(G \times-2179)\end{array}$ & $\begin{array}{l}\text { Detrital wood fragnents in sandy alluvium } \\
\text { beneast unoxidized till and above } \\
\text { oxidized il] }\end{array}$ & - & $\begin{array}{l}\text { Hamilton (1982, fig: } 13 \text { and } \\
\text { tables } 3 \text { and } 4)\end{array}$ \\
\hline
\end{tabular}




\begin{tabular}{|c|c|c|c|c|}
\hline Upper Tarana River valley & $\begin{array}{l}25,800 \pm 800 \\
(W-1[74)\end{array}$ & $\begin{array}{l}\text { Organic zone at base of eolian sand } \\
\text { beneath gravelly ort wash }\end{array}$ & - & Hamiliton (1982, fig. 13) \\
\hline $\begin{array}{l}\text { Farding Lake, middle Tarana } \\
\text { River valley }\end{array}$ & $\begin{array}{c}26,500 \pm 400 \\
(W-4817)\end{array}$ & Shallow-lake sedinents in core & Top of interstadial anit & Ager and Brabaker (1985) \\
\hline \multirow[t]{2}{*}{$\begin{array}{l}\text { Isabella Cretk basin, } \\
\text { Faibanks area }\end{array}$} & $\begin{array}{l}34,900 \pm 2,950 \\
(1-3083)\end{array}$ & Shreds of organics, including twigs & Pollen zone Aa & Mathews (1974) \\
\hline & $\begin{array}{l}>31,900 \\
(1-4775)\end{array}$ & $\begin{array}{l}\text { Small amomnt of fine-grained organic } \\
\text { residve from frozen organic silt }\end{array}$ & Pollen zore Ab & Do. \\
\hline \multirow[t]{2}{*}{$\begin{array}{l}\text { Fox permafrost unnel, } \\
\text { Fairbanks ares }\end{array}$} & $\begin{array}{l}32,790 \pm 560 \\
\text { (USGS-2S53) }\end{array}$ & $\begin{array}{l}\text { Silty peat with abundant roots over } \\
\text { unoncaled ice wedge }\end{array}$ & Thaw-pond sedinents & $\begin{array}{l}\text { Harwition and others (1988, } \\
\text { fig } 12 \text { and uble } 1 \text { ) }\end{array}$ \\
\hline & $\begin{array}{l}35,500 \pm 2,400 \\
(1-12,658)\end{array}$ & $\begin{array}{l}\text { Peal and sod mal over truncated. } \\
\text { foliated ice wedge }\end{array}$ & do. & Do. \\
\hline \multirow[t]{2}{*}{$\begin{array}{l}\text { Antifreeze pond, Snag-Klurlan area, } \\
\text { sowithwestern Yukon Terrilory }\end{array}$} & $\begin{array}{r}27,100 \pm 390 \\
(G \$ C-1198)\end{array}$ & Otganic material is pollen zone 2 & $\begin{array}{l}\text { Inverted dates for zones } 1 \text { and } 2 \text { may } \\
\text { indicate age }>31,000 \text { yr for both } \\
\text { zones (Schweger and Janssens, } 1980 \text {. } \\
\text { p. 315) }\end{array}$ & Ramapton (1971, fig. 6) \\
\hline & $\begin{array}{r}31,500 \pm 700 \\
(\text { GSC-1048) }\end{array}$ & do. & do. & Do. \\
\hline \multirow[t]{6}{*}{ Northem St Elias Mountains } & $\begin{array}{c}29,600 \pm 460 \\
\text { (GSC-769) }\end{array}$ & $\begin{array}{l}\text { Woody organic material in silt beneath } \\
\text { Ecefield outwash II }\end{array}$ & Split of sandple Y-1385 & Denton (1974, table 1) \\
\hline & $\begin{array}{c}30,100 \pm 600 \\
(Y-1385)\end{array}$ & do. & -- & Do. \\
\hline & $\begin{array}{l}33,400 \pm 800 \\
(Y-1488)\end{array}$ & do. & -- & Do. \\
\hline & $\begin{aligned} 37,700 & +1,500 \\
-1,300 & \end{aligned}$ & do. & OAdest finite date & Do. \\
\hline & $\begin{array}{l}(Y-1356) \\
>35,000 \\
(G S C-734)\end{array}$ & do. & Split of sample Y-1356 & Do. \\
\hline & $\begin{array}{l}>49,000 \\
(Y-1486)\end{array}$ & Peat stringer in base of Iceficld till & $\begin{array}{l}\text { Initiacion of Boutellier nonglacial } \\
\text { interval }\end{array}$ & Do. \\
\hline $\begin{array}{l}\text { Middle Fork Royukuk River. } \\
\text { central Brooks Range }\end{array}$ & $\begin{array}{c}28,450 \pm 950 \\
(\mathrm{I}-10,816)\end{array}$ & Wood beriealh periglacial fan & - & Hamilton (1986, table 5) \\
\hline \multirow[t]{2}{*}{ Naaluk River valley } & $\begin{array}{l}30,070 \pm 470 \\
\text { (USGS-1835) }\end{array}$ & $\begin{array}{l}\text { In-situ roos in alluvium below Itkillik } \Pi \\
\text { end moraine }\end{array}$ & -- & Do. \\
\hline & $\begin{array}{l}34,840 \pm 950 \\
\text { (USGS-1836) }\end{array}$ & do. & - & Do. \\
\hline \multirow[t]{2}{*}{$\begin{array}{l}\text { Epiguruk bluff, central } \\
\text { Kobak River valiey }\end{array}$} & $\begin{array}{l}33,690 \pm 960 \\
\text { (USOS-16S9) }\end{array}$ & Wood and pent in peat bed & -- & Do. \\
\hline & $\begin{array}{l}34,900 \pm 320 \\
\text { (USGS-1444) }\end{array}$ & Willow wood in peat bed & - & Do. \\
\hline
\end{tabular}


Table 4. Radiocarbon dates indicating timing of last recession of late Pleistocene ice in general area of Valdez Creek Mine

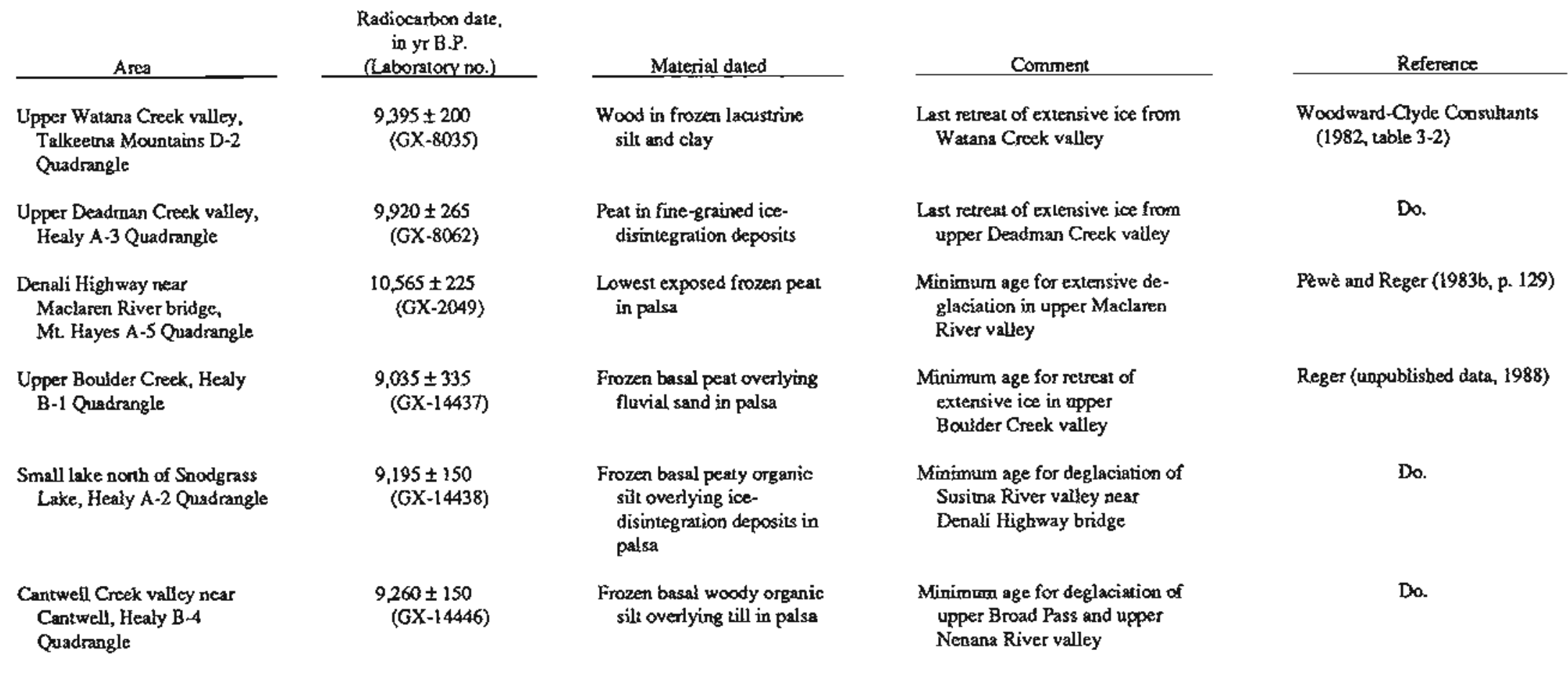

Do. $=$ Ditto. 
1982; Hamilton and Thorson, 1983; Kline, 1983; Pèwè and Reger, 1983b; Porter and others, 1983; Ten Brink, 1983; Ten Brink and Waythomas, 1984).

\section{INUNDATION BY GLACIAL ICE}

Following deposition of the rippled fine sand at the top of the thick lacustrine section (Fig. 3, unit 11), outwash (fig. 3, unit 12) invaded the area of pit A5 and was followed by the arrival and passage of glacial ice. During this glaciation, the upper till in pit AS (fig. 3, unit 13) was deposited along with ice-stagnation gravels (fig. 3, unit 12). Eventually, glacial ice in lower Valdez Creek valley thinned and retreated from the VCM areat. During postglacial time, a surface loess (nig. 3, unit 14) was deposited and pedogenic processes produced a moderatc soil profile (fig. 3, unit 15).

We contend that the last major glaciation of Valdez Creek valley probably took place in late Wisconsin time. Evidence for this argument is the late Wisconsin age for most of the thick lacustrine section (fig. 3, units 7 through 11) beneath the outwash and icecontact units (fig. 3, units 12 and 13); soil development in the surface locss and in the upper part of the till (fig. 3, unit 15) documents significant Holocene weathering after glacial ice left the area. Further, physiographic evidence indicates that lower Valdez Creek valley was glaciated during the Hatchet Lake advance of the Susitna River lobe, which fronted in waters of a late Wisconsin ice-dammed lake that had a surface elevation between 3,016 and 3,218 ft (914 and $975 \mathrm{~m}$ ) in the northwestern Copper River basin (Williams and Galloway, 1986).

The timing of late Wisconsin glaciation in the central Alaska Range is well documented by numerous published radiocarbon dates (Hamilion, 1982; Woodward-Clyde Consultanls, 1982; Hamilton and Thorson, 1983: Pèwè and Reger, 1983b; and especially Ten Brink, 1983; and Ten Brink and Waythomas, 1984). Regionally, ice expansions began close to 25,000 yr ago, and late Wisconsin ice generally left mountain valleys as late as $9.500 \mathrm{yr}$ ago (Ten Brink, 1983: Ten Brink and Waythomas, 1984). Several radiocarbon dates demonstrate that Pleistocene ice last retreated from mountain valleys in the general area of VCM before 9,000 to 10,600 yr ago (table 4).

\section{AGE IMPLICATIONS}

Speculations on the formation and ages of paleochannel systems other than paleochanncl $A$ are relevant to the features found in pit A5. Knowing the age of paleochannel $A$ and the relative ages of the Tammany, A, and B systems allows us to deduce the most likely ages of Tammany and $B$ paicochannels. Palcochannel A cuts across palechanncl $\mathrm{B}$, was cut deeper into bedrock, and its profile is $61012 \mathrm{~m}$ lower than paleochannel $B$ (Jerry O'Connor, oral commun., 1988); therefore, paleochannel $A$ is younger than paleochannel B. Because we think paleochannel $A$ is Sangamon in age, we speculate that paleochannel B probably formed during a late Illinoian interstadial episode of stream erosion and placer formation. Tammany paleochannel was cut 9 to $12 \mathrm{~m}$ decper into bedrock than paleochannel $A$ and 18 to $21 \mathrm{~m}$ deeper than paleochannel B (Jerry O'Connor, oral commun., 1989); it also cuts across both paleochannels $A$ and $B$ (fig. 2) and therefore postdates boch. We speculate that Tammany paleochannel was cut in mid-Wisconsin (probably Boutellier) time when the local base level was significantly lowered following the retreat of glacial ice.

\section{GLACIAL HISTORY OF VALDEZ CREEK VALLEY AND VICINITY}

Landform evidence for widespread former glaciation of the Valdez Creek area was quickly recognized by carly day geologists (Moffit, 1912). Tuck (1938, p. 123) noted a few localities where bedrock bencalh sorted gravels is glacially striated, and he identified evidence for two ice advances in the area. He concluded (Tuck, 1938, p. 123) that the moraine in the vicinity of Denali was deposited by a sluggish lobe of the Susiena River glacier. Nichols (in Smith, 1981, lig. 29) idenlified prominent moraines and ice limits in the area and auributed them to three glacial advances: $G_{1}$ (Denali) = early Wisconsin; $G_{2}$ (Hatchet Lake) = late Wiscon$\sin (?)$; and $G_{3}$ (Alpine Creek) = early Holocene(?). Smith $(1981$, pl. 1) mapped a prominent late Wisconsin end moraine that was deposited in the vicinity of Denali by ice derived from Valdez Creek valley and concluded that the last ice invasion of the VCM area came from Valdez Creek valley.

The purposes of our glacial-geologic investigation were to verify or modify previous mapping of glacigenic landforms and to relate past glaciations 10 known or likely sources of lode gold and known placers. In this study, former glacier limits and related landforms were traced on 1:51,420-scale black-and-white aerial photographs (M860, negatives 237-241) taken August 29, 1949, and on 1:65,000-scalc infrared acrial photographs (ALK $60 \mathrm{ClR}$, negatives 6112-6122) taken July 19, 1980. These fcaures were subsequently plotted on the 1:63,360-scale topographic base map of the Healy A-1 Quadrangle (sheet 1). The results of this preliminary study were then related to cuidence in pit AS, VCM, to develop an integrated model of past glaciacion for the Valdez Creek area. 


\section{GLACIAL EXTENTS}

We recognize evidence for four distinct glacial episodes in the Valdez Creek area. Physiographic evidence of these episodes reflects varying degrees of postglacial modification of the corresponding glacial deposits and landforms in that progressively younger glacigenic landforms and deposits are consistenty less altered by geomorphic agents.

\section{FIRST GLACIATION}

The storied cross profile of Valdez, Creck valley displays the most obvious physiographic evidence for the earlicst recognized glaciation in Valdez Creek vallcy. Only a deeply dissected, sloping remnant of the old glacial-vallcy wall is prescrved between about 4,200 and $5,400 \mathrm{fl}(1,270$ and $1,640 \mathrm{~m})$ elevation on the upper south-facing wall of the vallcy, $1,000 \mathrm{ft}(300 \mathrm{~m})$ above the modern floor (sheet 1). No primary morainal form rcmains recognizable there, and bedrock structures are widely visible on acrial photographs of the bedrock surface, indicating that former deposits have almost entirely been removed. Former ice limits of this age are inferred from highly modified ice-marginal channels cut into bedrock on the former glacial floor subparallel to modern contours (sheet 1). By comparison, the former ice-scoured south wall of Valdez Creek valley was virtually destroyed by vigorous subsequent alpine glaciation. All landforms there postdate the carliest known glaciation in the area, except possibly subtle notches and changes in slope between 4,400 and 4,900 ft $(1,330$ and $1,485 \mathrm{~m}$ ) elevation along the crests of some ridges bclwecn fresh, decply scoured glacial troughs (sheet 1).

Ice distribution during the earliest glaciation is nol well known because most surfaces glaciated then were destroyed by later glaciation and by later slope and stream processes. Glaciers of this age apparently reached a present elevation of at least $5,500 \mathrm{ft}(1,670 \mathrm{~m})$ along the north wall of Valdez Creek valley, but tenuous evidence is preserved only as high as 4,600 to $5,000 \mathrm{ft}(1,390$ to $1,515 \mathrm{~m})$ on the south side of the valley (shcet 1 ).

\section{SECOND GLACIATION}

Ice limits of the second glaciation are inferred from discontinuous ice-marginal channels on the lower north wall at the mouth of Valdez Creek valley, from poorly preserved lateral moraines and subule slope breaks across colluvial blankets on slopes 400 to $1,200 \mathrm{ft}(12010360 \mathrm{~m})$ above modern noors of lower Valdez Creek and Timberline Creek valleys, and from three well-modified end moraines on upper Craig Creek (sheet 1). Ocher ice-modified surfaces inferred to have bcen scoured during this major advance are present between 4,500 and $5,000 \mathrm{ft}(1,360$ and $1,515 \mathrm{~m})$ elevation in the notch between Gold Hill and Lucky Hill and on the upland between Roosevelt Creek and upper Valdez Creek (shcet 1). Quarrying and scouring by ice of the second glaciation were responsible for shaping most of the modern topography of Valdez Creek valley, including the inner lower valley, which is insel into the bedrock trough of the first glaciation. We do not recognize cirques occupied only by ice of this age; cirques of the second glaciation were probably reoccupied and deepened by ice of the third glaciation.

Till of the second glaciation blankets the floor and lower walls of lower Valdez Creek valley. Slope processes, primarily frost creep, solifluction, and gelifluction, have greatly modified or buried deposits of this advance there but have not completely stripped them from glaciated bedrock surfaces.

Ice of the second glaciation spread from source cirques at the head of mountain valleys in the Valdez Creek area and joined to form a compound valley-glacier system that, in turn, combined with other ice streams flowing south from Boulder Creek valley and down Susitna River valley (fig. 1). Local glaciers thickened enough to send a short lobe between Gold Hill and Lucky Hill into upper Lucky Gulch (sheet 1). Cross-cutting relations among ice-marginal channels and poorly preserved lateral moraines along the ridge north of VCM demonstrate that ice streams from Valdez Creek and Susitna River valleys did not fluctuate simultaneously (sheet 1). This situation was typical in the central Alaska Range, where short, relatively small glacier systems responded differently to climatic changes than long, relatively large glacier systems.

During the second glaciation, placer-gold-bearing till was deposited on bedrock in lower Valdez Creek valley by ice moving west to join the Susitna River lobe. Subsequent erosion and reworking of this till by stream and slope processes produced most of the rich gold placers in Tammany, $A$, and B paleochannets in VCM.' In addition, some gold was undoubtedly transported from bedrock sources by high-energy streams.

\section{THIRD GLACIATION}

Evidence is most widespread for the third glaciation in Valdez Creek valley. Landforms indicaling the former presence or passage of ice of this advance include horns; cirques; U-shaped, straight or slightly curved, steep-walled glacial valleys; aretes and notched ridge lines; ice-modified passes across ridges; medial, lateral, and end moraines; ice-disintegration deposits; sideglacial strearn gorges, channels, and related de- 
posits; and outwash trains and fans graded to coeval moraines (sheet 1 ). These features are generally wel preserved, except on steep slopes where slope processes have altered them.

Cirques of the third major advance have floors that range in elevation from 4,100 to $4,700 \mathrm{ft}(1,240$ to $1,425 \mathrm{~m})$ and average about $4,400 \mathrm{ft}(1,330 \mathrm{~m})$. Distribution of cirque headwalls is strongly skewed toward northern aspects, indicating that a critical relation among altitude, orientation, and solar radiation existed in the Valdez Creek area at this time, as it did in the Amphitheater Mountains to the east (Pèwè and Reger, 19836). Cirque walls are still sharp and steep, although talus has begun to form aprons on lower slopes. Arêtes remain jagged and continuous along higher ridges between closely spaced glacial troughs. Ice-scoured passes across lower ridges clearly document the partial diversion of ice from one valley into the next.

On the north valley wall, an upper limit of this glaciation is delineated by well-preserved, continuous to discontinuous lateral moraines with slightly rounded crests between elevations of $3,300 \mathrm{ft}$ and $4,500 \mathrm{ft}(1,000$ and $1,360 \mathrm{~m}$ ) (sheet 1); subtle surface breaks crossing slope colluvium connect morainal-ridge segments and mark zones where slope deposits have overwhelmed former moraines.

\section{Early phase}

In pit AS, deposits of the third glaciation form the entire section above the peat that caps the alluvial fill of paleochannel A (fig. 3, unit 4), except for Holocene loess (fig. 3, unit 14) and surface soil (fig. 3, unit 15). We recognized no tills of the early phase of the third glaciation in pit A5, nor did we see unconformities where till of this stade may have been eroded. Similarly, no unconformities or tills of this stade are apparent in cross sections that are based on tines of drill holes in lower Valdez Creek valley (VCMC, unpublished data). The clear implication is that lower Valdez Creek valley was ice free during the early phase of the third glaciation. However, units 5 and 6 in pit A5 (fig. 3) document at least temporary damming of the mouth of Valdez Creek valley during this early phase, probably by ice flowing south down Susitna River valley from cirques on the south side of the central Alaska Range.

\section{Late phase}

As previously mentioned, there is disagreement in the Jiterature over the source of the last glacial ice to occupy the VCM area. Distribution of till overlying lake deposits in several cross sections prepared by
VCMC geologists from numerous drill holes in lower Valdez Creek valley demonstrates that the last ice to invade the VCM area came from Susitna River valley and flowed eastward into the Valdez Creck valley reentrant as far as $0.8 \mathrm{~km}$ above the junction of Timberline and Valdez Creeks. Also, Teller (written commun., 1989) interprets folded lake sediments exposed high in the southeast wall of VCM to have becn deformed by ice flowing up Valdez Creek valley from Susiena River valley. Drill records and the pit A5 section record impoundment of a large ice-marginal lake in lower Valdez Creek valley when late-stade ice in Susitna River valley inicially blocked Valdez Creek valley. Drill-hole observations indicate that late-phase ourwash from the Susitna River lobe was deposited on top of the lake deposits as far as $2.5 \mathrm{~km}$ up Valdez Creek valley from the ice margin.

The maximum downvalley extent of glacial ice from the headwaters of Valdez Creek during the late phase of the third glaciation, according to logs of holes drilled as deep as $75 \mathrm{~m}$ to bedrock along lines across the lower valley perpendicular to the creek (VCMC, unpublished da(a), is the end-moraine couplet $3 \mathrm{~km}$ west of the junction of White and Valdez Creeks (sheet 1).

Compositions of glacial deposits in the lower valley of White Creek indicate that flow directions in late-stade ice streams changed, probably in response to changes in rates of ice production in different accumulation areas. These deposits conlain diorite enatics and gamets not found in the White Creek drainage; they also concain two suites of gold nuggets, one pale in color and well worn and the other bright and rough with attached pieces of quartz gangue (Moffit, 1912, p. 64; Tuck, 1938, p. 454; Smith, 1981, p. 59). These exotic constituents indicate that the ice that brought them into lower White Creek valley actually came from the valley of Valdez Creek around the north end of the Gold Hill-Lucky Hill upland.

Recession of the compound glacier up Valder. Creek during the waning phase of the third glaciation was characterized by several stillstands and perhaps minor readvances, as documented by a series of four nested morainal loops on the main valley floor between the confluences of White and Roosevelt Creeks with Valdez Creek (sheet 1). During this interval, tributary glaciers occupying the valleys of the Rusty Creeks, White Creek, and Roosevelt Creek separated from the main ice suream in Valdez Creek valley. Patterns of moraines of the third glaciation in the high-level pass between upper Valdez Creek and Boulder Creek to the north demonstrate that north-facing cirques at about $4,700 \mathrm{ft}(1,425 \mathrm{~m})$ elevation on the ridge north of Grogg Lake (sheet 1) spread ice lobes out into the pass, where they thickened, coalesced, and flowed southwest through the pass into upper Valdez Creek. 
The final episode of the third glaciation in Valdez Creek valley consisted of minor readvances by most tributaries to the mouths of their valleys (sheet 1). Bulky arcuate moraines blocking valley mouths and damming Pass, Roosevelt, and Tenas Lakes (sheet 1) imply that final-phase glaciers remained extended for a considerable time (perhaps several centuries) before final retreat to source cirques at the end of the third glaciation. The distibution of sharp-crested, arcuate lateral and end moraines between 4,500 and $5,000 \mathrm{fl}$ $(1,360$ and $1,515 \mathrm{~m})$ elevation on the small plateau at the head of Valdez Creek (sheet 1) indicates that a small ice cap of this late phase was centered over Grogg Lake. Ice tongues spread down surtounding mountain valleys as far as $3.9 \mathrm{~km}$ from this ice-accumulation center (sheet 1).

Colluvium interfingers with sideglacial-stream alluviurn and impinges on the edges of ice-marginal stream deposits of the third glaciation; postglacial fans from valley-side gullies locally bury sideglacial alluvium. Rock glaciers tentativcly assigned to this age occupy cirques between 4,100 and $5,000 \mathrm{ft}(1,240$ and $1,515 \mathrm{~m}$ ) elcuation at the heads of Timberline and Fourth of July Crecks (sheet 1). Protalus ramparts of equivalent age formed on less sheltered slopes between 4,600 and $5,300 \mathrm{ft}(1,390$ and $1,605 \mathrm{~m})$ elevation.

\section{FOURTH GLACIATION}

Features of the most recent ice expansion in Valdez Creek valley include very fresh cirques (some containing small active glaciers) and sharp-crested, frequently ice-cored, blocky lateral and end moraines. During the last few thousand years, glaciation in the Valdez Creek area has been restricted to upper moun. tain valleys. Headwalls of most cirques of this age face northwest, north, and northeast away from strongest solar radiation. Cirque floors, bearing fresh evidence of ice scouring, and young moraines, many retaining ice cores, range in elcuation from 4,500 to $5,300 \mathrm{fl}(1,360$ to $1,600 \mathrm{~m})$, an average of about 4,900 it $(1,485 \mathrm{~m})$ (sheet 1). Productive cirques of this age generated simple valley glaciers up to $1.6 \mathrm{~km}$ long that left moraines as low as 4,700 to $5,100 \mathrm{ft}(1,425$ to $1,545 \mathrm{~m})$ elevation.

Rock glaciers of equivalent age range in average elevation from about 4,600 to $5,500 \mathrm{ft}(1,390$ to $1,670 \mathrm{~m})$, an average of about $4,900 \mathrm{ft}(1,485 \mathrm{~m})$. Many of these rubble tongues formed by secondary flow of ice-cored moraines and represent up to three generations of activity; many of these debris tongues and benches are still active. In areas of former heavy snow accumulation near wind-swept ridge crests between 4,600 and $5,600 \mathrm{n}(1,390$ and $1,700 \mathrm{~m})$, an average of about
$5,000 \mathrm{ft}(1,515 \mathrm{~m})$, inacive procilus ramparts form sharp-crested rubble ridges around the toes of former perennial snow banks. A large rock avalanche of this age was produced by massive failure of the zoned alkali gabbro that composes the large horn at the head of Eldorado Creek (sheet 1; Smith, 1981, pl. 1).

\section{AGE AND CORRELATION}

Ages and relations among the four glaciations studied in the Valdez Creek area and glacial chronologies previously established for this part of the Alaska Range are based on comparisons of landform expression or stratigraphic evidence or both.

\section{FIRST GLACIATION}

The well-dissected nature of the ice-scoured upper stary of the north wall of Valdez Creek valley and the lack of bedrock cover there are typical of terrains glaciated in middle Pleistocene time in this part of the eastcentral Alaska Range (Pèwè, 1961, 1965, 1975). Realizing that correlations of middle Pleistocene glaciations are tenuous at best because of fragmentary evidence, we broadly correlate the earliest glaciation recognized in the Valdez Creek area with the Darling Creek and other pre-Illinoian glaciations in the Alaska Range (fig. 7).

\section{SECOND GLACIATION}

Landforms of the second major glaciation are highly modifiod by erosion and slope processes so that preserved macrorelief features are well rounded, extensively dissected, and widely buried by slope debris. However, deposits of this age are not stripped from icescoured bedrock surfaces nearly as much as deposits of the first glaciation. The advanced state of dissection and stripping of the high-level valley-floor remnant in Valdez Creck valley compared to subsequently glaciated topography is evidence that a major period of weathering and erosion occurred between the first and second glaciations. We interpret the storied character of Valdez Creek valley to be the result of bedrock incision during an ice-free time after the first glaciation and before the second glaciation.

Our best evidence for the age of the second glaciation was exposed in pit A5 of VCM. Large. granitic erratic boulders concentraced in the bottom of paleochannel A (fig. 3, unit 1) and similar boulders scattered throughout the gravel fill of paleocharnel $A$ (fig. 3, unit 2) and forming the cobble-boulder lag (fig. 3, unit 3) are remnants of a till that was derived from Valdez Creek valley and that predates cuting and 


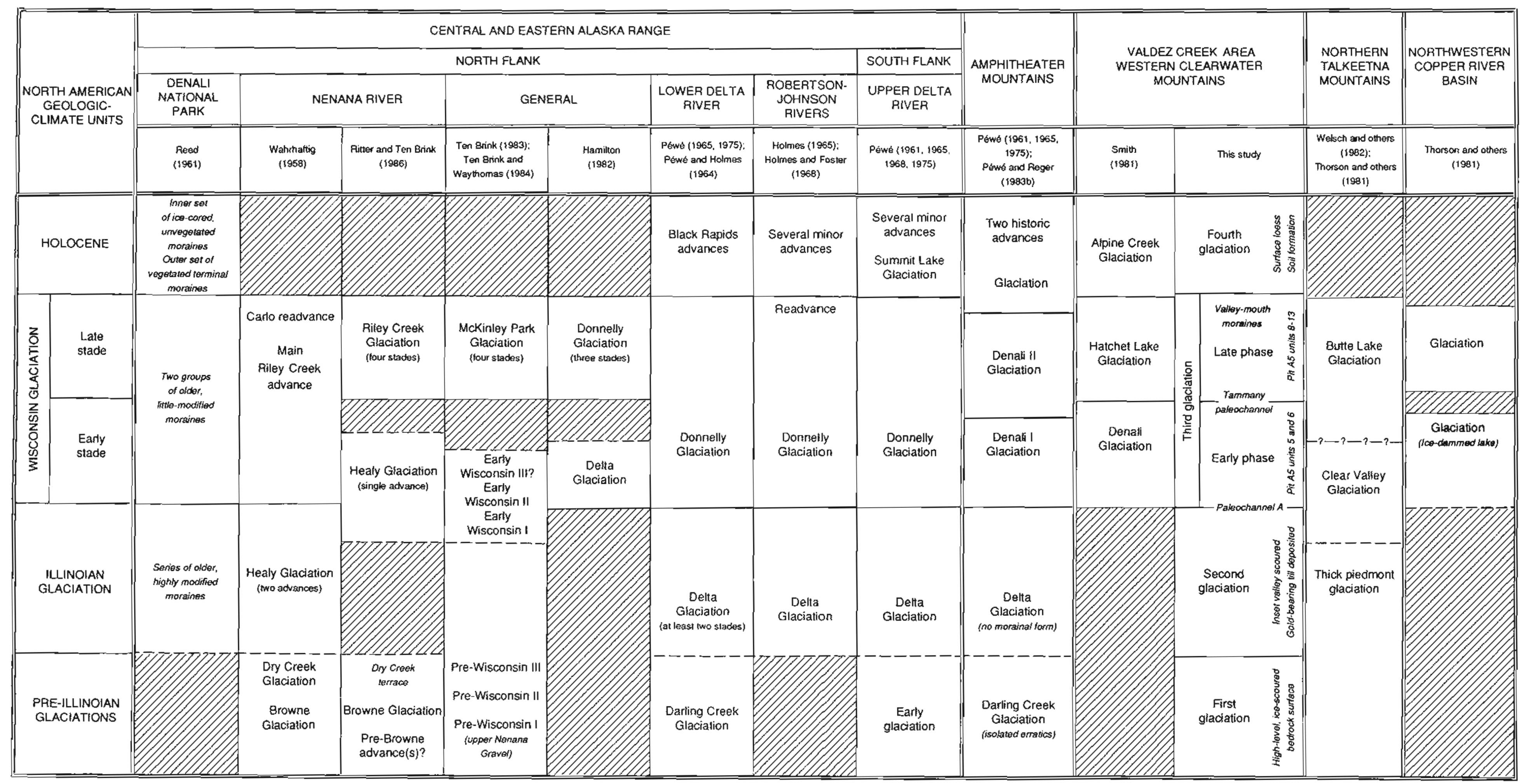

Figure 7. Comparison of glacial chronologies in vicinity of Valdez Creek area. 
filling of paleochannel A. In this report, we present two infinite radiocarbon dates and one probably infinite collagen radiocarbon date for the fill of paleochannel A (fig. 3). We appreciate the possibility that these dates do not completely preclude an early Wisconsin age for the channel fill. However, the presence of up $1030 \mathrm{~cm}$ of highiy compressed peat on top of the fill (fig. 3, unit 4) and the presence of the Iragmented proboscidean tusk in the fill reinforce an interglacial (Sangamon) age for the fill. The tusk implies that glaciers had receded in the Alaska Range to a degrec that passes between VCM and unglaciated eastern Beringia were open to mammal migration. Thus, the second glaciation, which deposited gold-bearing till in the VCM arca, is probably Illinoian in age (Fg. 7).

The second glaciation in the Valdez Creck area was probably simultaneous with widespread piedmont glaciation in the Amphitheater Mountains to the east, which Pewe (1961, 1965, 1975) called the Delta Glaciation, and in the northem Talkectna Mountains to the southwest (Welsch and others, 1982) (fig. 7). Although evidence for the areal distribution of the second glaciation remains to be evaluated south of the Valdez Croek area, it was coextensive with the Delta Glaciation, which spread through the Gulkana Upland into the Copper River basin far to the south (Pèwd, 1961, 1965; Pewd and Reger, 1983b).

\section{THIRD GLACIATION}

Radiocarbon ages and other stratigraphic evidence in pit AS of VCM provide documentation for two major stades within the third glaciation (fig. 7). Units deposited during the early stade (fig. 3 , units 5 and 6 ) postdace cuting and filling of paleochannel $A$ during the Sangamon interglaciation. A minimum age for deposits of the early stade is provided by the radiocarbon date of $25,900+3,000-1,900$ yт B.P. (fig. 3, sample GX-14433) for unit 7, which is just above unit 6 (fig. 3). This date, although slightly suspect because of its large statistical variation, indicates that the underlying fan-delta sand and inferred distal-outwash gravel are pre-late Wisconsin in age. Thus, we correlate the early stade of the third glaciation with early Wisconsin events elsewhere in this region (ng. 7). This same radiocarbon date and the pollen sample taken from the base of the lower parn of unit 8 (fig. 3) establish that units 8 through 13 in the upper part of the pit A5 section are late Wisconsin in age and correlate with late Wisconsin events in the Alaska Range, Amphicheater Mountains, Talkeetna Mountains, and Copper River basin (frg. 7).

Stratigraphic relations discovered during exploratory drilling demonstrate that outwash and morainal deposits of local derivation on the valley floor west of the junction of White and Valdez Crecks interfinger with and overlie lake deposits of late Wisconsin age that extend in the subsurface upvalley from the VCM area (VCMC, unpublished daca) (sheet 1). Thus, these morainal deposits are late Wisconsin and not early Wisconsin in age. Apparently, in early Wisconsin time ice derived from Susitna River valley blocked the mouth of Valdez Creek valley long enough to form an ice-marginal lake, but ice did not actually occupy the site of pit A5 in VCM as it did in late Wisconsin time. The lack of recognizable early Wisconsin moraines in Valdez Creek valley also leads us to conclude that late Wisconsin advances from southern Alaska Range and Valdez Creek sources were more extensive in this area than carly Wisconsin advances.

\section{FOURTH GLACIATION}

The extreme freshness and ice-cored character of many small moraines of the last ice advance in Valdez Creek valley, their limited extent relative to known late Wisconsin moraincs, and their close proximity to small modern glaciers suggest a Holocene age. Landforms of this episode, both glacial and periglacial, are identical in surface expression to Holocene equivalents elsewhere in the central Alaska Range (fig. 7).

\section{IMPLICATIONS FOR DISTRIBUTION OF PARTICULATE GOLD}

\section{INTRODUCTION}

Gold placers represent end products of a complex of processes, including erosion of gold and gold-bearing gangue materials, transportation by one or more geomorphic agents, deposition, subsequent erosion, further concentration, and final deposition (Schumm, 1977: Schumm and others, 1987); rich placers generally require several cycles of reworking. Agents of erosion and transportation include running water, waves and currents in bodies of scanding water, wind, and glaciers. An understanding of the ramifications of glaciation on placer distribution provides a rationale for locating undiscovered placers in the Valdez Creek area.

Glaciers effoctively scour and pluck bedrock and carry away all types of material, including precious melals (Sugden and John, 1976). Where glacial ice is thick, scouring and plucking are intense and large volumes of mineralized bedrock can be milled rapidly (Bundtzen, 1980). During glaciation, precious metals are initially deposited directly from melting ice in subglacial (lodgment) or superglacial (ablation) tills in concentrations that are not economic. Typically, meltwater streams then rework these deposits, perhaps beneath the 
ice but most often in front of the ice, further concentrating valuable melals and, in some cases, producing rich placers. For example, on South Island, New Zealand, valuable gold placers are present in eskers, kames, and outwash gravels (Williams, 1974). Most of the ice-transported gold on the island was deposited secondarily by proglacial streams near the front of ice sheets or tongues and by reworking of till along major drainage courses during glacier recession. Gold content in glaciofluvial deposits is generally highest near the former ice terminus and decreases with increasing dislance beyond it.

The geologic setting of the Valdez Creek area suggests that glaciation had a major role in the forma. tion of gold placers there. Most pieces of gold in VCM placers at the mouth of the valley bear the characteristic morphological signatures of glacial abrasion (round to subround shape, flatness, smooth surfaces), which require at least $1,000 \mathrm{~m}$ of ice transportation (Averill, 1988), although these forms may also result from several kilometers of high-energy stream transport. In contrast, the majority of nuggets recovered from placers in tributary sureams such as Timberline Creek, White Creek, and Lucky Gulch are still shiny, coarse, rough, and contain inclusions or attachments of gangue minerals, primarily quartz (Moffit, 1912; Ross, 1933; Tuck, 1938). These picces have not been significantly modified by glacial and stream abrasion; they are probably close to their bedrock sources.

\section{POTENTIAL BEDROCK SOURCES OF GOLD}

Placer gold has boen recovered in the drainage of Valdez Creck on several tributaries, including Rusty Creek, Little Rusty Creek, Big Rusty Creek, White Creek, Eldorado Creek, Roosevelt Creek, Surprise Creck, Lucky Gulch, and Timberline Creck (Smith, 1981; Balen, in press) (sheet 1). Geologic mapping and geochemical analyses of rock chips and stream sediments by Smith (1970b, c, 1981) identificd gold lodes and bedrock-related gold gcochemical anomalies in the argillite belt near Timberline Creck, Black Creek, Gold Hill-Lucky Hill and Surprise Creek (shoet 1). Wiltse identified gold-bearing quartz-carbonate-chlorite veins intimately associated with intensely sheared porphyritic andesite dikes that crosscut black phyllite, green phyllite, and monzodionite in the vicinity of Lucky Hill, Gold Hill, and the Yellowhorn prospect (Wittse, 1988; Wiltse and Reger, 1989) (shcet 1).

A mineralized porphyritic quartz monzodionite intrusive, thought to be an extension of the group of small intrusives mapped by Smith (1981, pl, 1) on Timberline Creek and on lower Valdez Creek, was exposed during excavation of pil A6, phase III, in early May 1989 (Jim Wachter, oral commun., 1989). The presence of this porphyry raises the interesting possibility of a local bedrock source for the small percentage of rough gold nuggets with attached gangue material that is recovered during VCMC operations.

Elsewhere in the drainage, Smith (1970b, fig. 7) documented a single gold anomaly in pelitic schist northwest of Surprise Creek (sheet 1). In the same area, U.S. Bureau of Mines geologists (unpublished data, 1988) recovercd small quantities of fine-particulate gold from placer concentrates, rock chips, and fine-grained stream-sediment samples taken from the drainages of Surprise, upper Valdez, and Grogg Creeks (Balen, in press) (shcet 1).

It has long been known that the north tributaries of Valdez Creek have yielded hardly any placer gold (Moffit, 1912). Therefore, medium- and high-grade metamorphic rocks and the quarz diorite intousion there are probably not potential sources of lode gold (Smith. 1981, pl. 1).

The consistent fineness (852) of most placer gold recovered from VCM (Smith, 1941; VCMC unpublished data) and the long-identified bedrock sources in the vicinity of the Gold Hill-Lucky Hill upland support previous conclusions by Moffil (1912). Tuck (1938), and Smith (1981) that most of the placer goid in Valdez Creek valley came from lodes in the Gold Hill-Lucky Hill area.

\section{A PLACER-EXPLORATION MODEL}

On the basis of past glacial extents relative to known and indicated gold lodes and known placers in the Valdez Creck area, we propose six targets where significant potential exists for locating valuable gold placers derived from lode sources in the Valdez Creek drainage (table S).

\section{EXTENSIONS OF KNOWN BURIED PALEOCHANNELS}

In his seismic profiles I and II, Smith (1970a, figs. 3 and 4) illustrated his interpretation that considerabie unexploited, potentially placer-bearing gravel fill remains along the east side of the Dry Creek cut in VCM. Other reaches of the ancient Denali palcochannel system where viable gold placers probably exist are located in upchannel and downchannel directions (sheet 1; table 5).

The highest potential for locating valuable gold placers in the Valdez Creek area is upchannel of known buricd channels (shect 1; Lable 5). Subsurface drilling by VCMC indicates that the incised paleochannel 
Table 5. Exploration targets for placer-gold deposits in Valdez Creek valley

\begin{tabular}{|c|c|c|}
\hline Tareal & $\begin{array}{c}\text { Inferred } \\
\text { placer poueniala }\end{array}$ & $\begin{array}{l}\text { Inferred } \\
\text { placer age }\end{array}$ \\
\hline Upchannel extensions of known buried paleochannels & High & Sangamon and Pootellier \\
\hline Downchannal extensions of known buried paleochannels & Moderale to high & Do. \\
\hline Other unexploited buried palcochannels & do. & Do. \\
\hline $\begin{array}{l}\text { Primary medial-moraine deposits downvalley from Gold } \\
\text { Hill-Lucky Hill area }\end{array}$ & do. & $\begin{array}{l}\text { Tlinoian, early, Wisconsin(?), } \\
\text { and lace Wisconsin }\end{array}$ \\
\hline $\begin{array}{l}\text { Zones downslope of known lodes where colluvium and lacenal } \\
\text { moraines are reworked by sideglacial sureams, including de- } \\
\text { posits in abandoned mele water chensels within lateral moraines }\end{array}$ & Maderute wo low & Late Wisconsin \\
\hline $\begin{array}{l}\text { Zones where end, madial, and lateral moraines of late Wisconsin } \\
\text { age are breached and reworked by axial and tributary streams }\end{array}$ & do. & $\begin{array}{l}\text { Late Wisconsin and } \\
\text { Holocene }\end{array}$ \\
\hline
\end{tabular}

system exposed in the mine extends upvalley at least $6 \mathrm{~km}$ but that discrete paleochannels cannot be easily differentiated (Jim Wachter and Robert Petersen, oral commun., 1989). The cover of unconsolidated deposits ovcrlying the paychannel $6 \mathrm{~km}$ upvalley from VCM is up to $75 \mathrm{~m}$ thick (VCMC, unpublished data).

Significant placer resources may also exist in buried alluvial fans of Sangamon and Boutellier age downchannel from VCM (sheet 1; table 5), as indicated by the presence of only about 5-percent fine gold (minus 200 mesh) in VCM placers (VCMC, unpublished data; U.S. Bureau of Mines, unpublished data). The coarse size and structures of gravel fills in VCM paleochannels indicate that high-energy depositional environments existed at least intermittently during placer formation. In this vigorous environment, fine gold not locally trapped around large clasts would be flushed downstream to eventually be deposited in relarively low-energy environments on alluvial fans just beyond the bedrock channel, similar to the setting of gold placers associated with Porcupine Creek in the Porcupine mining district of southeastern Alaska (Bundtzen, 1986; Hoekzema and others, 1986). We propose that there is moderate to high potential for localing valuable placers of fine gold in downstream proximal fan sediments because (1) gold placers arc probably deeply buried there, and (2) the bedrack knob west of VCM could have protected preexisting placerbearing sediments from scour by glacial ice in Susitna River valley (sheet 1; table 5). We speculate that gold concentrations in buried fan deposits will be less than that currently mined in paleochannel A of VCM and will have lobate distributions because of shifting depositional loci and dilution by rapid sedimentation. Gold values will probably be highest close to fanheads unless fanhead dissection shifted placers downfan (Schumm and others, 1987).

\section{OTHER UNEXPLOITED PALEOCHANNELS}

Although Smith (1970a, fig. 1) showed the approximate cxtent of an arcuate bedrock channel subparallel $L$ and south of the gorge of Valdez Creek, we believe that depressions in his profiles I, II, III, and $\Gamma$ could be evidence of a more extensive, northeasttrending, possibly branching paleochannel system subparallel to the nearby VCM Dry Creek cut and parallel to the Tammany palcochannel system north of Valdez Creek (sheet 1). Seismic-refraction data indicate that this buried paleochannel is cut about $8 \mathrm{~m}$ into phyllitic argillite bedrock. Bccause particulate gold is widespread in the bench gravels, we assign a moderate to high potential that the shallowly buried paleochannel system on Denali bench contains valuable concentrations of gold (table 5).

\section{PRIMARY MEDIAL-MORAINE DEPOSITS}

Several lines of evidence support glacial transport of most of the gold in VCM downvalley from the Gold Hill-Lucky Hill area when the inset (inner) valiey of Valdez Creek was scoured out during the second (Illinoian) glaciation:

1. The greatest known concentration of gold lades in Valdez Creek valley is in the Gold Hill-Lucky Hill area (sheet 1). 
2. Evenson and others (1982, 1984, 1985) demonstrated that lithologic and mineralogic compositions of moraines, especially medial moraines, in the central Alaska Range reliably reflect bedrock compositions and mineralization in morainal source areas. Sizes, shapes, and compositions of boulders in pay gravel of paleochannel $A$ indicate that they. were glacially transported from bedrock sources in Valdez Creek valley.

3. Debris-flow deposits in the gravel fill of paleochannel $A$, which represent little reworked till of the second glaciation, contain significant placer gold.

4. Remarkably consistent gold fineness (852) (Smith, 1941; VCMC, unpublished data) of nuggets in VCM placers indicates a common type of lode source for the nuggets.

5. Dominant nugget morphology is consistent with glacial transport of more than $1,000 \mathrm{~m}$ (Averill, 1988).

Our glacial-transport model predicts moderate to high potential for locating valuable gold placers in glacial drift between VCM and the Gold Hill-Lucky Hill upland (table 5), which stood as a nunatak above surounding glaciers during Illinoian, late Wisconsin, and perhaps early Wisconsin advances. The zone with the greatest chance of containing glacially transported detrital gold roughly follows the axis of Valdez Creek valley and coincides with deposits of medial moraines formed through the joining of gold-bearing lateral moraines scoured from the four sides of the Gold HillLucky Hill upland by tributary glaciers that occupied the valleys of Eldorado, Roosevelt, Valdez, and White Creeks (sheet 1). Also, we predict that the width of this belt remains fairly consistent in a westward (downvalley) direction because of the narrow valley width (Drake, 1983).

In addition to richness of the lodes eroded, gold values in morainal debris are determined by rates of bedrock quarrying and abrasion, which are influenced by flow velocities of former glaciers: faster ice velocities increase entrainment of gold into the moving glacier and slower ice velocities promote slow quarrying and increase rates of deposition (Clark, 1987). Concentrations of detrital gold in the medial-moraine belt probably decrease along a negative exponential-decay curve downvalley from the source area and eventually may approach a linear distribution (Shilts, 1976; Clark, 1987; Strobel and Faure, 1987). The exponential downvalley decrease is related to progressive dilution by nonauriferous material and to progressive comminution of particles by crushing and abrasion during transport in debris-rich ice. The area of consistent values is theoretically produced after gold particles are reduced to a terminal size (usually sand or silt) (Strobel and Paure, 1987); however, the travel distance in Valdez Creek valley may not have been adequate to reach this stage of particle comminution. In any case, the pattern of gold distribution within the medial-moraine deposits is probably complicated by multiple advances, nonuniform flow rates in and between former ice streams, multiple ore bodies, and reworking by subglacial and surface streams.

Surfaces of detrical gold carried in debris-rich ice become more rounded and polished in the downglacier direction by rubbing against other particles (Shilts, 1976; Clark, 1987; Averill, 1988). Most nuggets recovered from VCM placers exhibit this smooth morphological modification. The minority of rough gold pieces with attached gangue minerals in VCM represent either (1) detrital gold carried in debris-poor ice within the glacier, where clasts are not abraded (Shilts, 1976; Clark, 1987; Strobel and Faure, 1987), or (2) detrital gold released from nearby bedrock lodes.

\section{REWORKED VALLEY-SIDE COLLUVIUM AND LATERAL MORAINES}

Early prospectors and miners in the Valdez Creek area soon recognized the presence of coarse, angular detrital gold, many pieces with attached quarlz, and angular fragments of gold-bearing gangue material in colluvium that was in some cases mixed with glacial deposits and alluvial-colluvial fan gravels downslope from gold lodes in Lucky Gulch and in the valley of White Creek (Moffit, 1912; Ross, 1933; Tuck, 1938). Because eluvial placers in these valley-side sediments are likely to be small and spotty (Ross, 1933), we tentatively assign a moderate to low potential for locating valuable gold placers in them (table 5). However, nuggets as large as $52 \mathrm{oz}(1.5 \mathrm{~kg})$ have been recovered from these deposits in lower Lucky Gulch (Moffit, 1912).

During glaciation, ice margins are frequently the locations of meltwater streams that slightly rework adjacent slope and morainal deposits. Where gold lodes are present in bedrock sources of the till and colluvium, important placers are occasionally formed along glacier margins. For example, the rich high-bench placers of Dexter, Dry, and Anvil Creeks just north of Nome were formed through retransportation of gold-bearing colluvium and till by sideglacial streams of middle Pleistocene age (Collier and others, 1908; Moffit, 1913; Cobb, 1973). In the vicinity of the Gold Hill-Lucky Hill upland, Wiltse and Reger (1989) mapped deposits of late Wisconsin ice-marginal streams and abandoned 
meltwater channels that have significant placer potential (sheet 1). Placer-mining operations on White Creck visible in acrial photographs taken in 1949 followed these channel deposits.

\section{OTHER REWORKED MORAINES}

Following the New Zealand example in which fluvial gold placers are related to eroded glacial moraines (Williams, 1974), we propose that there exists a significant opportunity for finding valuable gold placers in the Valdez Creck area where gold-bearing end, medial, and lateral moraines of late Wisconsin age are breached and reworked by axial and tributary streams (table 5). Gold in these late Wisconsir and Holocene nuvial placers is cxtracted from till of glaciers that scoured known bedrock sources of gold in the drainages of Timberline, Rusty, Little Rusty, Big Rusty, White, Valdez, and Surprise Crecks (sheet 1 ). We expect that initial concentrations of gold in moraines of late Wisconsin age are too low to be economic, and it is only through fluvial reworking of the till that valuable placers developed. However, the likelihood of scveral cycles of placer reconcentration is slight duc to the brief time since deglaciation.

\section{CONCLUSIONS}

New information developed during this study indicates appropriate models for past glaciations and for the formation and locations of gold placers:

1. Stratigraphic observations in pit A5 of VCM and a brief photointerpretive study of the Vaidez Creek area provide evidence for pre-Illinoian, Illinoian, Wisconsin, and Holocene glaciations in the western Clearwater Mountains.

2. Pre-Illinoian glaciation scoured the ancient upper story of Valdez Creek valley, which is now dissected and preserved only on the north upper valley wall.

3. Inset lower Valdez Creek valley was scoured during the second (Illinoian) glaciation, during which local glaciers were tributary to the large trunk glacier that occupied the valley of Susitna River. Most of the placer gold in VCM was probably quarried from lodes in the Gold Hill-Lucky area and deposited initially in lower Valdez Creek valley in till of the second glaciation.
4. The early Wisconsin advance in the Valdez Creek area was clearly less extensive than the late Wisconsin advance, whether the ice was derived from Valdez Creek valley or from the Susitna River valley. During late Wisconsin time, ice of the Susitna River glacier blocked Valdez Creek valley, producing an extensive ice-marginal lake that drained catastrophically at least once before it was filled by varved scdiments, rippled lacustrine sand, outwash gravel, and till.

5. Drilling by VCMC geologists indicates that at least three principal and several other paleochannel systems were incised into bedrock in lower Valdez Creek valley. These paleochannels were filled by alluvial gravel and slightly retranspored till, boin containing valuable gold placers, during former interglaciations, interstades, or both, when deglaciation triggered significant lowering of local base levels. Inconclusive, but strongly suggestive, evidence indicates that paleochannel $\mathrm{A}$ is Sangamon in age and that Tammany paleochanncl is mid-Wisconsin (Boutellier) in age. Paleochanncl B was probably cut during a late Illinoian interstade.

6. Recognition that the early Wisconsin glaciation was less extensive than late Wisconsin advances in this par of the western Clearwater Mountains raises the possibility that buricd placers of pre-late Wisconsin age in other glaciated areas of Alaska are preserved within the limits of late Wisconsin glaciation.

7. Additional targets for undiscovered gold placers in the Valdez Creek area include (1) upchanncl extensions of known buried paleochannels, (2) buried fans composing downchannel extensions of known buried paleochannels, (3) other unexpioited buried paleochannels, (4) medial-moraine deposits downvalley from the Gold Hill-Lucky Hill upland, (5) former courses of ice-marginal meltwater streams that reworked goldbearing valley-side colluvium and ill, and (6) zones where gold-bearing end, medial, and lateral moraines were breached and reworked by late-glacial and posiglacial axial and tributary streams. 


\section{REFERENCES CITED}

Ager, T.A., 1982, Vegetational history of western Alaska during the Wisconsin glacial interval and the Holocene, in Hopkins, D.M. Mathews, J.V., Jr., Schweger, C.E., and Young, S.B., eds., Paleoecology of Beringia: New York, Academic Press, p. 75-93.

1983, Holocene vegetational history of Alaska, in Wright, H.E., Jr., ed., Late-Quaternary environments of the United States, Volume 2, The Holocene: Minneapolis, Universily of Minnesota Press, p. 128-140.

1989, History of late Pleistocene and Holocene vegetation in the Copper River basin, south-central Alaska, in Caner, L.D., Hamiton, T.D., and Galloway, J.P., eds., Late Cenozoic history of the interior basins of Alaska and the Yukon: U.S. Geological Survey Circular 1026, p. 89-92.

Ager, T.A., and Brubaker, Linda, 1985, Quatemary palynology and vegetational history of Alaska, in Bryant, V.M., Sr, and Holloway, R.G., cds., Pollen records of late-Quaternary North American sediments: Dallas, American Association of Stratigraphic Palynologists Foundalion, p.353384.

Averill, S.A., 1988, Regional variations in the gold content of cilt in Canada, in MacDonald, D.R., and Mills, K.A., cods., International Symposium on Prospecting in Areas of Glaciated Terrain, 8th, Halifax, Nova Scotia, 1988, Proccedings: Canadian Institute of Mining and Metallurgy, p. 271284.

Balen, M.D., in press, Results of 1988 Bureau of Mines investigations in the Valdez Creek mining district, Alaska: U.S. Burcau of Mines Open-filc Rcport $31-89,156 \mathrm{p}$.

Bressler, J.R., Jones, W.C., and Cleveland, Gaylord, 1985. Geology of a buricd channel sysicm at the Denali placer gold mine: The Alaska Miner, v, 13, no. 1, p. 9 .

Bundizen, T.K., 1980, Geological guides to heavy mineral placers: Annual Conference on Alaska Placer Mining, 2nd, Fairbanks, 1980, Procecdings: University of Alaska Mineral Industry Research Laboratory Repont 46, p. 21-44.

1986. Placer geology of the Porcupine mining district, Skagway B-4 Quadrangle, Alaska: Alaska Division of Geological and Geophysical Surveys Public-data File Report 86-27, 25 p.

Bundtzen, T.K., Eakins, G.R., Clough, J.G., Lueck, L.L., Green, C.B., Robinson, M.S., and Coleman, D.A., 1984, Alaska's mineral industry--1983:
Alaska Division of Geological and Geophysical Surveys Special Report 33, 56 p.

Bundzzen, T.K., Eakins, G.R., Green, C.B., and Lueck, L.L., 1986, Alaska's mineral industry-1985: Alaska Division of Geological and Geophysical Surveys Special Report 39,68 p.

Bundaen, T.K., Green, C.B., Deagen, James, and Daniels, C.L., 1987, Alaska's mineral industry-1986: Alaska Division of Geological and Geophysical Surveys Special Report 40, 68 p.

Carter, L.D., Hamilton, T.D., and Galloway, J.P., 1989, Late Cenozoic history of the interior basins of Alaska and the Yukon: U.S. Geological Survey Circular 1026, $114 \mathrm{p}$.

Cheney, E.S., and Patton, T.C., 1967, Origin of the bedrock values of placer deposits: Economic Geology, v. 62, no. 6, p. 852-853.

Clark, P.U., 1987, Subglacial sediment dispersal and till composition: Journal of Gcology, v. 95, no. 4, p. $527-541$.

Cobb, E.H., 1973, Placer deposits of Alaska: U.S. Geological Survey Bulletin 1374, $213 \mathrm{p}$.

Collicr, A.J., Hess, F.L., Smith, P.S., and Brooks, A.H., 1908, The gold placers of parts of Seward Peninsula, Alaska, including the Nome, Council, Kougarok, Port Clarence, and Goodhope precincts: U.S. Geological Survey Bullctin 328, 343 p.

Connor, C.L., 1983, Late Pleistocene paleocnvironmental history of the Copper River basin, southcentral Alaska, in Thorson, R.M., and Hamilton, T.D., eds., Glaciation in Alaska: Exiended abstracts from a workshop: University of Alaska Museum Occasional Paper 2, p. 30-34.

1984, A middle Wisconsin pollen record from the Copper River basin, Alaska, in Coonrad, W.L., and Elliou, R.L., eds., The United States Geological Survey in Alaska: Accomplishments during 1981: U.S. Geological Survey Circular 868, p. 102-103.

Cox, D.P., Light, T.D., Csejtey, Bèla, Jr., Campbell, D.L., and Yeend, W.E., 1989, Mineral resource assessment map of the Healy Quadrangle, Alaska: U.S. Gcological Survey Miscellaneous Field Studies Map MF-2058A, scale 1:250,000, 1 sheet.

Denton, G.H., 1974, Quaternary glaciations of the White River valley, Alaska, with a regional synthesis for the northern St. Elias Mountains, Alaska and Yukon Territory: Geological Sociely of America Bulletin, v. 85, no. 6, p. 871-892.

Dessauer, P.F., and Harvey, D.W., 1980, An historical resource study of the Valdez Creek mining district, Alaska--1977: Boulder, Westerm Interstate Commission for Higher Education (unpublished report prepared for U.S. Bureau of Land Management), $212 p$. 
Drake, L.D., 1983, Ore plumes in till: Joumal of Geology, v. 91, no. 6, p. 707-713.

Eakins, G.R., Bundtzen, T.K., Lueck, L.L., Green, C.B., Gallagher, J.L., and Robinson, M.S., 1985, Alaska's mineral indusiry--1984: Alaska Division of Geological and Geophysical Surveys Special Report 38, 57 p.

Evenson, E.B., Stephens, G.C., Curtin, G.C., and Tripp, R.B., 1982, Geochemical exploration using englacial debris, in Coonrad, W.L., ed., The United States Gcological Survey in Alaska: Accomplishments during 1980: U.S. Geological Survey Circular 844, p. 108-109.

Evenson, E.B., Stephens, G.C., and Detra, D.E., 1985, Bedrock mapping of remole areas using medial moraine debris from active glaciers, ML Hayes and Healy Quadrangles, in Bartsch-Winkler, Susan, ed., The United States Gcological Survey in Alaska: Accomplishments during 1984: U.S. Geological Survey Circular 967, p. 55-56.

Evenson, E.B., Stephens, G.C., Neher, F.R., King, H.D., and Detra, D.E., 1984, Mineral exploration and reconnaissance bedrock mapping using active alpine glaciers, Mount Hayes and Healy Quadrangles, southern Alaska, in Coonrad, W.L., and Elliout, R.L., eds., The United States Geological Survey in Alaska: Accomplishments during 1981: U.S. Geological Survey Circular 868, p. 94-95.

Ferrians, O.J., Jr., and Nichols, D.R., 1965, Copper River basin, in Pewe, T.L., ed., Guidebook for Field Conference $F$, central and south-central Alaska: International Association for Quaternary Research, 7th Congress, Fairbanks, 1965: Lincoin, Nebraska Academy of Sciences, p. 93-114; reprinted 1977, College, Alaska Division of Geological and Geophysical Surveys.

Hamilton, T.D., 1982, A late Pleistocene glacial chronology for the southern Brooks Range: Stratigraphic record and regional significance: Gcological Sociely of America Bulletin, v. 93, no. 8, p. $700-716$.

1986, Late Cenozoic glaciation of the central Brooks Range, in Hamilton, T.D., Reed, K.M., and Thorson, R.M., eds., Glaciacion in Alaska--The geologic record: Anchorage, Alaska Geological Sociecy, p. 9-49.

Hamilton, T.D., Craig, J.., and Sellmann, P.V., 1988, The Fox permafrost tunnel: A late Quatemary geologic record in central Alaska: Geological Sociefy of America Bulletin, v. 100, no. 6, p. 948 969.

Hamilton, T.D., and Robinson, S.W., 1988, Middle Wisconsin interstadial interval, central and northwest Alaska [abs.]: Geological Society of America
Abstracts with Programs, v. 20, no. 7, p. A208A209.

Hamilton, T.D., and Thorson, R.M., 1983, The Cordilleran ice sheet in Alaska, in Porter, S.C., ed., Late-Quaternary environments of the United States, Volume 1, The late Pleistocene: Minneapolis, University of Mirnesota Press, p. 38-52.

Heusser, CJ., 1983, Vegetational history of the northwestern United States including Alaska, in Porter, S.C., ed., Late-Quaternary environments of the United States, Volume 1, The late Pleistocene; Minneapolis, University of Minnesota Press, p. 239-258.

Hoekzema, R.B., Fechner, S.A., and Bundzen, Tom, 1986: Distribution, analysis, and recovery of placer gold from Porcupine mining ares, southcast Alaska: U.S. Bureau of Mines Open-file Report 89-86, $49 \mathrm{p}$.

Holmes, G.W., 1965, Geologic recornaissance along the Alaska Highway, Delta River to Tok Junction, Alaska: U.S. Geological Survey Bulletin 1181-H, $19 \mathrm{p}$.

Holmes, G.W., and Fosier, H.L., 1968, Gcology of the Johnson River area, Alaska: U.S. Geological Survcy Bulletin 1249, $49 \mathrm{p}$.

Hopkins, D,M., 1967, The Bering Land Bridge: Stanford, Stanford Universicy Press, $495 \mathrm{p}$.

Hopkins, D.M., Matthews, J.V., Jr., Schweger, C.E., and Young, S.B., 1982, Paleoecology of Beringia: New York, Academic Press, 489 p.

Hughes, R.A., 1989, The Denali placer gold mine: The Alaska Miner, v. 17, no. 10, p. 14-15, 19.

Kline, J.T., 1983, Preliminary Quatemary glacial chronology for the Farewell area, McGrath Quadrangle, Alaska, in Thorson, R.M., and Hamilton, T.D., cds., Glaciation in Alaska: Excended abstracts from a workshop: University of Alaska Museum Occasional Paper 2, p. 57-61.

Kline, J.T., and Bundtzen, T.K., 1986, Two glacial records from west-central Alaska, in Hamilton, T.D., Reed, K.M., and Thorson, R.M., eds., Glaciation in Alaska--The geologic record: Anchorage, Alaska Geological Sociery, p. 123150.

Kontrimavichus, VL., 1984, Beringia in the Cenozoic Era: New Delhi, Amerind Publishing Company, $724 \mathrm{p}$.

Matthews, J.V., Jr., 1974, Wisconsin environment of incerior Alaska. Pollen and macrofossil analysis of a 27-meter core from the Isabella basin (Fairbanks, Alaska): Canadian Journal of Earth Sciences, v. 11, no. 6, p. 828-841.

1982, East Beringia during late Wisconsin time: A review of the biotic evidence, in Hopkins, 
D.M., Mathews, J.V., Jr., Schweger, C.E., and Young, S.B., eds., Paleoccology of Beringia: New York, Academic Press, p. 127-150.

Moffit, F.H., 1912, Headwater regions of Gulkana and Susitna Rivers, Alaska, with accounts of the Valde' Creek and Chistochina placer districts: U.S. Geological Survey Bulletin 498, 82 p.

1913, Geology of the Nome and Grand Central Quadrangles, Alaska: U.S. Geologica) Survey Bulletin 533, $140 \mathrm{p}$.

Pèwè, T.L., 1961, Mulciple glaciation in the headwaters area of the Delta River, central Alaska, in Short papers in the geologic and hydrologic sciences, 1961: U.S. Geological Survey Professional Paper 424-D, p. D200-D201.

1965, Delta River area, Alaska Range, in Pèwè, T.L., Ferrians, O.J., Jr., Nichols, D.R., and Karlstrom, T.N.V., Guidebook for Ficld Conference $F$, central and south-central Alaska, International Association for Quaiernary Researcts, 7th Congress, Fairbanks, 1965: Lincoln, Nebraska Academy of Sciences, p. 55-93; reprinted 1977. College, Alaska Division of Geological and Gcophysical Surveys.

1968, Loess deposits of Alaska: Inicrnational Geological Congress, 23rd Session, Prague, 1968, Proceedings, v. 8, p. 297-309.

1975, Quaternary geology of Alaska: U.S. Geological Survey Professional Paper 835, 145 p.

Pèwe, T.L., and Holmes, G.W., 1964, Geology of the ML. Hayes D-4 Quadrangle, Alaska: U.S. Gcological Survey Miscellaneous Geologic Investigations Map [-394, scale 1:63,360, 2 sheets.

Pèwe, T.L., and Reger, R.D., 1983a, Middle Tanana River valley, in Pewè, T.L., and Reger, R.D., eds., Guidebook to permafrost and Quaternary geology along the Richardson and Glenn Highways between Fairbanks and Anchorage, Alaska: Alaska Division of Geological and Geophysical Surveys Guidebook 1, p. 5.45 .

1983b, Delta River area, Alaska Range, in Pèwè, T.L., and Reger, R.D., eds., Guidebook to permafrost and Quatemary geology along the Richardson and Glenn Highways between Fairbanks and Anchorage, Alaska: Alaska Division of Geological and Gcophysical Surveys Guidebook 1, p. 47-135.

Pèwe, T.L., Reger, R.D., and Westgate, J.A., 1989. Fairbanks area, in Pèwè, T.L., and Reger, R.D., eds., Quatemary geology and permafrost along the Richardson and Glenn Highways between Fairbanks and Anchorage, Alaska: 28 th International Geological Congress Field Trip Guidebook T102: Washington, D.C., American Geophysical Union, p. 3-16.
Porter, S.C., Pierce, K.L., and Hamilton, T.D., 1983, Late Wisconsin mountain glaciation in the western United States, in Porter, S.C., ed., Late-Quaternary environments of the United States, Volume 1, The late Pleistocene: Minneapolis, University of Minnesota Press, p. 71-111.

Post, Austin, and Mayo, L.R., 1971, Glacier-dammed lakes and outburst floods in Alaska: U.S. Geological Survey Hydrologic Investigations Atlas HA455, 10 p., scale 1:1,000,000, 3 shcets.

Ramplon, Vem, 1971, Late Quatemary vegetational and climatic history of the Snag-Klutan area, southwestem Yukon Territory, Canada: Geological Society of America Bulketin, v. 82, no. 4, p. 959978.

Reed, J.C., Jr., 1961, Geology of the Mount McKinley Quadrangle, Alaska: U.S. Geological Survey Bulletin $1108-\mathrm{A}, 36 \mathrm{p}$.

Richmond, G.M., and Fullerton, D.S., 1986, Introduction to Quatemary glaciations in the United States of America, in Sibrava, V., Bowen, D.Q., and Richmond, G.M., eds., Quaternary glaciacions in the Northern Hemisphere: Quaternary Science Reviews, v. 5, p. 3-10.

Ritchie, J.C., 1984, Past and present vegetation of the far northwest of Canada: Toconto, Universicy of Toronto Press, 251 p.

Ritchie, J.C., and Cwynar, L.C., 1982, The late Quaternary vegetation of the north Yukon, in Hopkins, D.M., Mathews, J.V., Jr., Schweger, C.E., and Young, S.B., eds, Paleoecology of Beringia: New York, Acadernic Press, p. 113-126.

Ritter, D.F., and Ten Brink, N.W., 1986, Paraglacial fan formation and glacial history, Nenana valley, Alaska: Joumal of Geology, v. 94, no. 4, p. 613625.

Ross, C.P., 1933, The Valdez Creek mining districe, Alaska: U.S. Geological Survey Bulletin 849-H, p. 425-468.

Schumm, S.A., 1977, The fluvial system: New York, John Wiley, $338 \mathrm{p}$.

Schumm, S.A., Mosłey, M.P., and Weaver, WE., 1987, Experimental fluvial geomorphology: New York, John Wiley, $413 \mathrm{p}$.

Schweger, C.E., 1982, Late Pleistocene vegetation of eastern Beringia: Pollen analysis of dated alluvium, in Hopkins, D.M., Matthews, J.V., Jr., Schweger, C.E., and Young, S.B., eds., Paleoccology of Beringia: New York, Acadomic Press, p. 95-112.

Schweger, C.E., and Janssens, J.A.P., 1980, Palcoecology of the Boutellier nonglacial interval, St Elias Mountains, Yukon Territory, Canada: Arctic and Alpine Research, v. 12, no. 3, p. 309317. 
Shits, W.W., 1976, Glacial till and mineral exploration, in Legget, R.F., ed., Glacial till: An interdisciplinary study: Royal Society of Canada Special Publication 12, p. 205-224.

Smith, P.S., 1933, Past placer gold production from Alaska: U.S. Geological Survey Bulletin 857-B, p. 93-98.

1941, Fineness of gold from Alaska placcrs: U.S. Geological Survcy Bullctin 910-C. $272 \mathrm{p}$.

Smith, T.E., 1970a, Gold resource potential of the Denali bench gravels, Valdez Creck mining district, Alaska: in Geological Research 1970: U.S. Geological Survey Professional Paper 700-D, p. D146-D152.

1970b, Results of geochemical sampling in the western Clearwater Mountains, Alaska: U.S. Geological Survey Open-file Report 441, 249 p.

1970c, Lode gold occurrences in the wcstem Clearwater Mounlains [abs.], in Geological Survcy Research 1970: U.S. Geological Survey Professional Paper 700-A, p. A47.

1981, Geology of the Clearwater Mountains, south-central Alaska: Alaska Division of Geological and Geophysical Surveys Gcologic Report 60, 72 p.

Strobel, M.L., and Faure, Gunter, 1987, Transport of indicator clasts by ice shects and the transporl half-distance: A contribution to prospecting for ore dcposits: Joumal of Geology, v. 95, no. 5, p. 687 697.

Sugden, D.E., and John, B.S., 1976, Glaciers and landscape: New York, John Wiley, $376 \mathrm{p}$.

Teller, S.D., and Bressler, Jason, in press, Gold placer mineralization and gold weathering, Denali Mine, Valdez Creek discrict, Alaska, in Gold '88 Symposium, Melbourne, Australia, 1988, Proceedings.

Ten Brink, N.W., 1983, Glaciation of the northern Alaska Range, in Thorson, R.M., and Hamilton, T.D., eds., Glaciation in Alaska: Extended abstracts from a workshop: University of Alaska Museum Occasional Paper 2, p. 82-91.

Ten Brink, N.W., and Waychomas, C.F., 1984, Late Wisconsin glacial chronology of the north-central Alaska Range--a regional synthesis and its implications for early human settlements, in Ten Brink, N.W., ed., North Alaska Range Project final report on 1978-1982 geoarcheological siudies to National Geographic Sociely and National Park Service, Part 5, p. 5-1 through 5-32.

Tharson, R.M., Dixon, E.J., Jr., Smith, G.S., and Batcen, A R., 1981, Interstadial proboscidean from southcentral Alaska: Implications for biogeography, geology, and archcology: Quatemary Research, v. 16, no. 3 , p. $404-417$.
Tuck, Ralph, 1938, The Valdez Creck mining district, Alaska, in 1936; U.S. Geological Survey Bulletin 897-B, p. 109-131.

Wahrhaftig, Clyde, 1958, Quaternary and engineering geology in the central part of the Alaska Range: U.S. Geological Survey Professional Paper 293-A. p. $1-70$.

Welsch, Dennis, Goodwin, Robert, and Ten Brink, Norman, 1982, Late Quatemary glaciations of the Talkeetra Mountains, Alaska [abs.]: Geological Society of America Abstracts with Programs, v. 14, no. 6, p. 353-354.

Williams, G.J., 1974, Detrilal gold, in Williams, G.J., ed., Economic geology of New Zealand: Australasian Institule of Mining and Metallurgy Monograph 4, p. 69-86.

Williams, J.R., 1989, A working glacial chronology for the western Copper River basin, Alaska, in Canter, L.D., Hamilton, T.D., and Galloway, J.P., eds., Late Cenozoic history of the interior basins of Alaska and the Yukon: U.S. Gcological Survey Circular 1026, p. 81-84.

Williams, J.R., and Galloway, J.P., 1986, Map of westem Copper River basin, Alaska, showing lake sediments and shorelines, glacial moraines, and location of stratigraphic sections and radiocarbondated samples: U.S. Geological Survey Open-file Report 86-390, 30 p., scale 1:250,000, 1 sheet.

Wimmler, N.L., 1925, Placer mining in Alaska in 1925: Alaska Territorial Department of Mines Report MR 195-8, p. 58-72.

Wiltse, M.A., 1988, Preliminary lithogeochemistry of Gold Hill and Lucky Hill, Valdez Creek mining discrict. Healy A-1 Quadrangle, southcentral Alaska: Alaska Division of Geological and Geophysical Surveys Public-data File Report 88-41, 7 p., scale 1:12,000, 1 sheet.

Wilsse, M.A., and Reger, R.D., 1989, Geologic map of Gold Hill and Lucky Hill, Valdez Creek mining district, Healy A-1 Quadrangle, Alaska: Alaska Division of Geological and Geophysical Surveys Public-data File Report 89-5, scale 1:12,000, 1 sheet.

Woodward-Clyde Consultants, 1982, Quatemary geology, in Final report on seismic studies for Susitna Hydroelectric ProjecL Buffalo, unpublished reporl prepared for Acres American Incorporated, p. 3-1 through 3-20.

Yeend, W.E., 1984, Placers and placer mining in the Healy Quadrangle, southern Alaska, in Coonrad, W.L., and Elliott, RL., eds., The United States Geological Survey in Alaska: Accomplishments during 1981: U.S. Geological Survey Circular 868, p. 95-99. 
STAFF ${ }^{1}$

Robert B. Forbes, State Geologist

Thomas E. Smith, Deputy State Geologist

\author{
Administrative Services \\ P.M. Verosta, Administrative assistant ${ }^{2}$ \\ K.E. Brown, Clerk typist \\ R.A. Czajka, Clerk typist \\ R.R. Groner, Accounting technician \\ M.G. Murphree, Clerk typist \\ J.M. Robinson, Administrative assistant \\ J.L. Weir, Field office assistant
}

\section{Energy Resources}

G.H. Pessel, Geologist ${ }^{2}$

J.G. Clough, Geologist

S.A. Liss, Geologist

R.J. Motyka, Geologist

C.G. Mull, Gcologist

J.W. Reeder, Geologist

R.R. Reifenstuhl, Geologist

M.S. Robinson, Geologist

Engineering Geology

R.A. Combellick, Geologist ${ }^{2}$

G.D. March, Geologist

C.J. Nye, Geologist

R.D. Reger, Geologist

M.A. Wiltse, Chemist

Minerals and Materials Development

W.G. Gilbert, Geologist 2

T.K. Bundtzen, Geologist

L.E. Burns, Gcologist

K.H. Clautice, Geologist

E.E. Harris, Geologist

J.T. Kline, Geologist

D.N. Solie, Geologist
Resource Information

G.M. Laird, Publications specialist ${ }^{2}$

K.E. Adams, Publications technician

R.A. Mann, Clerk

J.A. Outten, Clerk typist

A-L. Schell, Cartographer

A.F. Seward, Publications techrician

A.G. Sturmann, Cartograpber

\section{Water Resources}

W.E. Long, Hydrologist ${ }^{2}$

R.D. Alley, Hydrologist

S.J. Carrick, Hydrologist

M.G. Inghram, Hydrologist

R.W. Ireland, Hydrologist

D.L. LaSage, Hydrologist

M.A. Maurer, Hydrologist

MA. Moorman, Hydrologist

J.A. Munter, Hydrologist

R.S. Noll, Hydrologist

W. A. Petrik, Hydrologist

\footnotetext{
${ }^{1}$ In addition to the permanent stafr histed above, DGGS presentify cmploys 14 students in the Department of Natural Resources Student Intern Program.

ISection chicr.
} 